\title{
Role of the Cytoskeleton in Formation and Maintenance of Angiogenic Sprouts
}

\author{
Kayla J. Bayless ${ }^{\text {a }}$ Greg A. Johnson ${ }^{b}$ \\ ${ }^{a}$ Department of Molecular and Cellular Medicine, Texas A\&M Health Science Center, and \\ ${ }^{b}$ Veterinary Integrative Biosciences Department, Texas A\&M University, College Station, Tex., USA
}

\section{Key Words}

Actin • Endothelial • Intermediate filament · Tubulin •

Vimentin

\begin{abstract}
Angiogenesis is the formation of new blood vessels from pre-existing structures, and is a key step in tissue and organ development, wound healing and pathological events. Changes in cell shape orchestrated by the cytoskeleton are integral to accomplishing the various steps of angiogenesis, and an intact cytoskeleton is also critical for maintaining newly formed structures. This review focuses on how the 3 main cytoskeletal elements - microfilaments, microtubules, and intermediate filaments - regulate the formation and maintenance of angiogenic sprouts. Multiple classes of compounds target microtubules and microfilaments, revealing much about the role of actin and tubulin and their associated molecules in angiogenic sprout formation and maintenance. In contrast, intermediate filaments are much less studied, yet intriguing evidence suggests a vital, but unresolved, role in angiogenic sprouting. This review discusses evidence for regulatory molecules and pharmacological compounds that affect actin, microtubule and intermediate filament dynamics to alter various steps of angiogenesis, including endothelial sprout formation and maintenance.
\end{abstract}

Copyright $\odot 2011$ S. Karger AG, Basel

\section{Introduction}

Angiogenesis is defined as new blood vessel growth from previously existing structures and occurs naturally in the placenta and uterus during pregnancy, in the ovary during follicle development, ovulation and corpus luteum formation, and during wound healing in healthy adults. In pathological conditions, uncontrolled angiogenesis can occur, resulting in various diseases and cancer $[1,2]$. Under quiescent conditions, endothelial cells form a protective barrier and line the vasculature. The endothelium and the protective barrier normally present must adapt rapidly to accommodate angiogenic sprout formation, where endothelial cells migrate from a quiescent monolayer with stable junctions and form new blood vessels in response to extravascular pro-angiogenic cues. Angiogenesis is a multi-step process which involves endothelial cell activation, degradation of the basement membrane, invasion, proliferation, lumen formation and stabilization. This process is regulated by a balance of pro- and anti-angiogenic molecules. Several key factors include, but are not limited to, growth factors [3-9], bioactive lipids [10-13], integrins [14-21], junctional proteins [22-24] and transmembrane proteinases [25-29]. These molecules ultimately transduce intracellular signals to the cytoskeleton, which orchestrates the various steps in angiogenesis.

\section{KARGER}

(C) 2011 S. Karger AG, Basel

Fax +41613061234

E-Mail karger@karger.ch

www.karger.com
Dr. Kayla J. Bayless

Department of Molecular and Cellular Medicine, Texas A\&M Health Science Center 442 Reynolds Medical Building

1114 TAMU, College Station, TX 77843-1114 (USA)

Tel. +1 979845 7205, E-Mail kbayless@ medicine.tamhsc.edu 


\section{Actin}

Actin is a well-studied cytoskeletal element for controlling angiogenesis. An intact actin cytoskeleton is integral for cell motility and membrane protrusion events, which are key for mounting successful angiogenic responses. The actin cytoskeleton is tethered to the plasma membrane through adherens junctions and focal adhesions at cell-cell and cell-matrix contacts, respectively. As discussed in the sections below, inhibition of integrins, focal adhesions and cadherins [30-34] blocks angiogenic responses, indicating actin anchoring at these sites is critical to this process. Given the substantial evidence linking the above-described molecules associated with actin, it follows that the actin network and its associated proteins would be viable targets for anti-angiogenic therapies [for a review, see 35]. The reader is also referred to other extensive reviews on migration [36], integrins [37], junctional regulation $[22,38]$ and endothelial lumen formation [39] for further reading.

\section{Cell-Matrix Interactions}

Cell recognition and response to the extracellular matrix (ECM) is critical for successful sprouting responses. Blockade of various integrin subunits prevents angiogenic responses in multiple systems $[14,21,40-43]$. Integrin ligation results in activation of focal adhesion kinase, Ras, phosphoinositide-3 kinase-Akt signaling, mitogen-activated protein kinases, Src and Rac, Rho, and Cdc42 GTPases [44-47], in addition to other molecules not listed. Furthermore, recognition of the ECM by some integrins (such as $\alpha v \beta 3$ ) results in the phosphorylation of integrin cytoplasmic tyrosine residues, which in turn promotes recruitment of intracellular adaptor proteins $[48,49]$. Integrin knockout models suggest that functional compensation occurs between various integrin subunits, and that embryonic and adult vasculogenic and angiogenic events are controlled by distinct integrin subunits [50]. These data provide important insights into the ECM and integrins, which transduce downstream signals and promote angiogenesis in development and pathological situations.

\section{Small GTPases}

The Rho family of small GTPases are master regulators of the actin cytoskeleton [51] and have been shown to be involved in angiogenesis. GTPases are perfectly suited to regulate actin dynamics, which are key for cell motility, protrusion formation and establishing polarity. Cdc42 and Racl mediate endothelial lumen formation [52-54]. Fitting with these data, expression of Cdc42 and
Racl improved the architecture of pathological angiogenesis stimulated by VEGF administration $[55,56]$. Davis and colleagues [57] have provided biochemical evidence to link Cdc42 to the $\alpha 2 \beta 1$ integrin, which is required for lumen formation and endothelial morphogenesis. These data explain how matrix recognition of a pro-morphogenic substrate (such as collagen type I [58]) can induce endothelial lumen formation and sprouting responses, namely by coupling matrix recognition (via $\alpha 2 \beta 1)$ with cytoskeletal rearrangements (via Cdc42) and matrix proteolysis (via membrane type I matrix metalloproteinase, MT1-MMP) [57]. In addition, Cdc42 can form a polarity complex with atypical protein kinase $\mathrm{C}$ and protease activated receptor 3 (Par 3 ), which directs lumen formation and sprouting [59]. These data highlight that endothelial polarity is established during angiogenic responses, and that the Cdc42 and Racl GTPases are required for polarization.

In addition to Cdc42 and Rac1, the small GTPases Rho and Rap1 have been investigated in angiogenesis. Collagen type I activated Src kinase and Rho through $\beta 1$-integrins [60], and Rho activation stimulated endothelial cell assembly into new blood vessels in a mouse skin model of angiogenesis [61]. Further evidence for an involvement of Rho is provided by a report that Syx, a synectin-binding guanine exchange factor for Rho, may interact with angiomotin, an endothelial junctional protein, to direct sprouting [62]. Separate studies have demonstrated that silencing of the cerebral cavernous malformation 2 (CCM2) gene in endothelial cells activates Rho and impairs endothelial junctions to block vacuole and lumen formation but maintain initial sprouting responses [63]. Expression of dominant negative isoforms of Rho and treatment with $\mathrm{C} 3$ exoenzyme alone do not significantly alter vacuole and lumen formation [53], suggesting the additional change in junctional permeability contributes to a defect in lumen formation. Interestingly, CCM2 forms an intracellular complex with CCM1 and CCM3. CCM1 is also known as KRIT-1 and forms a complex with the Rap1 GTPase, which is involved in regulating endothelial permeability and junctional integrity $[64,65]$. In separate studies, Ras-associated protein 1 (Rap1), a small GTPase which associates with both integrins and cadherins, is required for angiogenesis [66], and is essential for the conformational activation of $\beta 1$-integrins and postnatal neovascularization in endothelial cells [67]. These studies emphasize important roles for small GTPases in mediating various steps of angiogenesis, and highlight that crosstalk between small GTPases and endothelial junctions is critical for successful angiogenic responses. 


\section{Junctional Proteins}

The endothelium lines the inner surface of the vascular system and is arranged as a monolayer. Another class of molecules involved in cell-cell communication that is integral in vessel organization and sprouting responses is the transmembrane adhesion receptors that maintain the integrity of endothelial junctions. Interendothelial junctions contain three complex junctional structures - including adherens junctions, tight junctions and gap junctions. Gap junctions are communication structures which allow the passage of small-molecular-weight solutes between neighboring cells. Tight and adherens junctions are mainly responsible for intercellular adhesion via the formation of actin filament-associated protein complexes along transmembrane adhesion sites [22] and regulate the permeability and organization of blood vessels $[23,24]$.

Vascular endothelial (VE)-cadherin is the major determinant of endothelial adherens junctions. In addition, regulation of VE-cadherin activity or its presence at cell contacts is essential for controlling vascular permeability. VE-cadherin, like other members of the cadherin family, is linked through its cytoplasmic tail to p120, $\beta$-catenin and plakoglobin. $\beta$-Catenin and plakoglobin bind to $\alpha$ catenin, which interacts with several actin-binding proteins, including $\alpha$-actinin, ajuba, zonula occludens- 1 (ZO-1) and others, forming a large and dynamic protein complex at cell contacts [68]. Tyrosine phosphorylation of $\beta$-catenin reduces its affinity for the cadherin cytoplasmic tail and increases its turnover at junctions, thereby destabilizing adherens junctions $[69,70]$. Mice deficient for VE-cadherin die at midgestation of vascular malformations [71]. Defects are more severe in the extraembryonic placental vasculature. No capillary plexus is formed in the allantois, although electron microscopy shows that interendothelial junctions do form. Thus, VE-cadherin seems dispensable for initial vasculogenesis, but is required for subsequent remodeling and vascular morphogenesis [71].

In addition to molecules responsible for maintaining junctional integrity, the Notch pathway has been reported to modulate angiogenesis $[72,73]$. Endothelial cells express Notch1 and Notch4 surface receptors, along with their ligands, Jagged1 and Jagged2 (homologs of Drosophila serrate-like proteins) and Delta-like 1 (DLL1) and DLL4. Notch signaling is initiated when the extracellular domain of the receptor recognizes ligand expressed on a neighboring cell, which cleaves the Notch receptor and releases the extracellular domain. The intracellular domain is released and translocates to the nucleus to acti- vate gene transcription [73]. Notch signaling regulates endothelial cell specification and the initiation of branching morphogenesis in multiple systems [74-78]. Interestingly, feedback may occur from cytoskeletal regulatory proteins to regulate Notch signaling. Cytoskeletal binding protein, CG3973, was recently identified as a transcriptional target of Notch signaling in Drosophila. CG3973 is a member of the Gas2-like family of proteins which have potential binding sites for both actin and microtubules. Roper and colleagues [79] have recently shown that CG3973 negatively regulates Notch signaling, because adult flies lacking CG3973 have higher levels of Notch activation in various tissues. Perhaps more interesting, new evidence is emerging that Notch ligands cross-talk with cell adhesion and cytoskeletal machinery. The cytoplasmic tail of Jagged- 1 contains a PDZ recognition motif that interacts with afadin, a molecule associated with adherens junctions [80]. These data suggest an additional connection to the cytoskeleton independent of an ability to activate Notch signaling. Altogether, these recent publications suggest an increased level of sophistication, where the cytoskeleton is integrated with Notch signaling. It remains to be demonstrated whether such cross-talk with the endothelial cytoskeleton and Notch signaling pathways occurs.

\section{Role for Proteins That Regulate \\ Membrane-Cytoskeletal Interactions}

Actin accessory and membrane scaffold proteins comprise an additional class of molecules that can regulate angiogenic responses. Three prominent actin-associated proteins are filamin, annexin 2 and moesin. Filamin isoforms $\mathrm{A}, \mathrm{B}$ and $\mathrm{C}$ stabilize and bridge F-actin networks to the plasma membrane through membrane receptors or ion channels [81]. In addition, filamins bind a diverse array of cellular proteins, some of which include the small GTPases Rho, Rac, Cdc42 and RalA, allowing assembly of signaling complexes in various systems [82, 83]. In endothelial cells, gene silencing of Filamin B increased focal adhesion assembly, reduced VEGF-induced migration and cord formation, and increased p21 activated kinase (PAK) activation; further, Filamin B formed a complex with Vav-2 and Rac1 [84]. These data stress a role for filamin in controlling endothelial migration and tube formation.

Annexin 2 is a multifunctional membrane scaffold protein that has been implicated in the formation of new blood vessels [85]. Annexin 2 binds F-actin and spectrin [86] and is thought to organize the interface between the cytoplasm and plasma membrane by interacting with 
membrane phospholipids and actin filaments $[87,88]$. Gene silencing studies indicate a role for annexin 2 in regulating adherens junctions, actin dynamics and tight junctions [89-92]. We have shown that annexin 2 is required for endothelial sprouting responses, and it complexes with VE-cadherin following endothelial stimulation with sphingosine 1-phosphate [93], a potent proangiogenic factor [94]. Annexin 2 depletion reduced endothelial barrier integrity and significantly reduced Akt phosphorylation, which suggests annexin 2 may control endothelial morphogenesis through an adherensjunction-mediated pathway upstream of Akt [93]. These data indicate a key role for annexin 2 in regulating endothelial sprouting responses.

Ezrin, radixin and moesin proteins interact with transmembrane proteins and the cytoskeleton. This feature allows these proteins to organize specialized membrane domains critical for signaling complexes [95]. Interestingly, endothelial cells express predominantly moesin, while epithelial cells and hepatocytes predominantly express ezrin and radixin $[96,97]$. Moesin is required for increased endothelial permeability responses to various cues, because knockdown of moesin blocks increases in permeability in response to TNF- $\alpha$ and other stimuli [ 98 , 99]. Essner and colleagues [100] report that moesin 1 is required for lumen formation in developing intersegmental vessels in the zebrafish embryo. Moesin knockdown ablated VE-cadherin-positive adherens junctions, but not tight junctions. These data suggest VE-cadherin and moesin 1 cooperate to establish and maintain endothelial polarity [100]. In separate studies, mice lacking moesin had delayed lumen formation in the dorsal aorta and a decreased amount of F-actin beneath the apical surface of the endothelium, which is where lumen formation is initiated [101]. In addition, CD34-sialomucins and podocalyxin were implicated with moesin, as well [101]. These studies reinforce that establishment of endothelial polarity is critical for proper angiogenic responses.

\section{Microtubules}

Microtubules normally ebb and flow and exhibit dynamic instability and treadmilling. Microtubule-binding drugs and vascular-disrupting agents are widely used to interfere with the formation of angiogenic structures and stimulate their collapse, which is also defined as breakdown or regression of existing structures. A summary of the effects of compounds that affect microtubule organization which have been used to study various steps in an- giogenesis is summarized in table 1. Microtubule-binding drugs and vascular-disrupting agents suppress the dynamics of microtubules without appreciably changing microtubule mass and are undergoing various clinical trials $[102,103]$. These agents have provided useful tools to demonstrate that tubulin polymerization and stabilization are required for formation and maintenance of angiogenic structures, respectively. Microtubule depolymerizing agents - such as ZD6126, AVE8062, combrestatin A4, CYT997, JG-03-14, TH-482, vinblastine and vinflunine - can destabilize existing vascular networks. Microtubule-depolymerizing agents can also block sprout formation and include colchicine, combrestatin A4, embellistatin, 2-methoxyestradiol (2-ME), spongistatin, tubulysin A and XRP44X. Microtubule-stabilizing compounds - including docetaxel, epothilone B, IDN 5390 , laulimalide and paclitaxel - also block sprout or cord formation. Thus, microtubule networks must remain intact for angiogenic network maintenance and stabilization, but also maintain dynamic properties that are required for the initial formation of angiogenic structures. Interestingly, intracellular levels of these compounds can accumulate in endothelial cells approximately 5 times higher than other cells [104-106].

\section{Consequences of Microtubule Alterations}

Microtubules are critical for successful cell division, intracellular transport and signaling. Microtubule-associated proteins are often misregulated in cancer, making tubulin and microtubules viable targets for chemotherapy. Microtubule targeting compounds are among the most effective classes of chemotherapeutics to prolong survival in patients with metastatic disease $[162,163]$. Described below are various intracellular pathways that are perturbed following microtubule disruption and stabilization. These include alteration of microtubule plus- and minus-end molecules, hypoxia-inducible factor (HIF) and various other processes. Microtubule flux is governed by regulation of microtubule growth at plus-ends and anchoring at minus-ends. Minus-end anchoring of microtubules originates at the centrosome with the aid of multiple accessory proteins. Ninein is one such microtubule minus-end anchoring protein [164, 165]. Ninein is phosphorylated as endothelial cells undergo tubulogenesis, and enhanced in tip cells in endothelial outgrowths from embryoid bodies embedded in 3-D collagen matrices [166]. Disruption of the plus-ends of microtubules similarly disrupts endothelial motility and tubulogenesis [158]. Low doses of vinflunine inhibited endothelial cell motility that correlated with EB-1 mislocalization at mi- 
Table 1. Microtubule altering compounds and their effects on angiogenesis

\begin{tabular}{|c|c|c|c|c|c|c|c|c|c|c|c|}
\hline \multirow[t]{2}{*}{ Compound } & \multirow[t]{2}{*}{ Class } & \multicolumn{6}{|c|}{$\begin{array}{l}\text { Effects on various steps of } \\
\text { angiogenesis in vitro }\end{array}$} & \multicolumn{2}{|c|}{$\begin{array}{l}\text { Vascular effects } \\
\text { in vivo }\end{array}$} & \multirow[t]{2}{*}{ Mechanism } & \multirow[t]{2}{*}{$\begin{array}{l}\text { Reference } \\
\text { No. }\end{array}$} \\
\hline & & 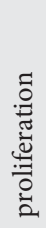 & 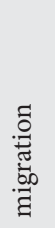 & 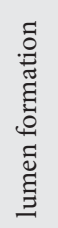 & 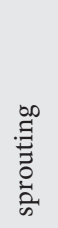 & 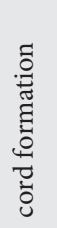 & 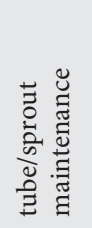 & 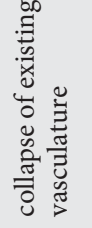 & 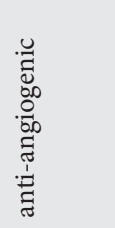 & & \\
\hline ABT-751* & $\mathrm{D}$ & & & & & & & & & $\begin{array}{l}\text { selectively targets tumor blood flow; } \\
\text { induces endothelial contraction in vitro }\end{array}$ & 107,108 \\
\hline $\begin{array}{l}\mathrm{N} \text {-acetylcolchinol } \\
(\mathrm{ZD} 6126)^{*}\end{array}$ & $\mathrm{D}$ & I & & & & & I & yes & & induces endothelial contraction & $109-112$ \\
\hline Albendazole & $\mathrm{D}$ & & & & & & & & yes & $\begin{array}{l}\text { suppresses ascites formation by blocking VEGF } \\
\text { production in ovarian carcinoma }\end{array}$ & 113,114 \\
\hline Ang-510 & $\mathrm{D}$ & & & & I & & I & & & $\begin{array}{l}\text { combrestatin-like compound; blocks } \\
\text { angiogenesis and disrupts newly formed vessels }\end{array}$ & 115 \\
\hline $\begin{array}{l}\text { AVE8062* } \\
\text { AC7700 }\end{array}$ & $\mathrm{D}$ & I & & & & & & yes & & $\begin{array}{l}\text { combrestatin A4 derivative; toxic to endothelial } \\
\text { cells in vitro; decreases blood flow and targets } \\
\text { host arterioles }\end{array}$ & $116-120$ \\
\hline Colchicine* & $\mathrm{D}$ & I & I & & I & I & & & & increases endothelial permeability & $121-124$ \\
\hline $\begin{array}{l}\text { Combrestatin A4 } \\
\text { (Zybrestat)* }\end{array}$ & $\mathrm{D}$ & I & I & & & I & I & yes & yes & $\begin{array}{l}\text { blocked phosphorylation of Net, a known } \\
\text { transcription factor involved in angiogenesis; } \\
\text { decreased tumor blood flow; increased tumor } \\
\text { blood flow }\end{array}$ & $102,125-130$ \\
\hline CYT997* & $\mathrm{D}$ & I & & & & & & yes & & increases endothelial permeability & 131 \\
\hline Docetaxel $^{*}$ & S & I & I & & & I & & & yes & disrupts F-actin & $132-137$ \\
\hline Embellistatin & $\mathrm{D}$ & I & I & & & I & & & yes & $\mathrm{G} 2 / \mathrm{M}$ arrest & 138 \\
\hline Epothilone B & S & & & & I & & & & & $\begin{array}{l}\text { blocks angiogenic outgrowth from human tumor } \\
\text { explants }\end{array}$ & 139 \\
\hline IDN $5390^{*}$ & S & & I & & & I & & & yes & & 140,141 \\
\hline JG-03-14* & $\mathrm{D}$ & & & & & I & I & & & $\begin{array}{l}\text { increased endothelial permeability and inhibited } \\
\text { VEGF-induced VE-cadherin phosphorylation }\end{array}$ & 142 \\
\hline Laulimalide* $^{*}$ & S & I & I & & & I & & & & $\begin{array}{l}\text { blocked paxillin phosphorylation; } \\
\text { distinct binding site from paclitaxel }\end{array}$ & $133,143,144$ \\
\hline M410 & $\mathrm{D}$ & I & & & & & & & yes & decreased HIF- $1 \alpha$ and VEGF & 145 \\
\hline $\begin{array}{l}\text {-ME } \\
\text { (Panzem)* }\end{array}$ & $\mathrm{D}$ & I & I & & I & I & & & yes & $\begin{array}{l}\text { can synergize with docetaxel to mask } \\
\text { pro-angiogenic effects of VEGF }\end{array}$ & $\begin{array}{l}123,124 \\
134,146,147\end{array}$ \\
\hline $\begin{array}{l}\text { Paclitaxel } \\
\text { (Taxol)* }\end{array}$ & S & I & I & & I & I & & & yes & can downregulate VEGF production & $\begin{array}{l}124,135 \\
136,147-149\end{array}$ \\
\hline Spongistatin & $\mathrm{D}$ & I & I & & I & I & & & yes & $\begin{array}{l}\text { blocks PKC } \alpha \text { activity and translocation to } \\
\text { membrane }\end{array}$ & 150 \\
\hline TH-482 & $\mathrm{D}$ & I & & & & I & I & & & increases endothelial permeability & 151 \\
\hline Tubulysin $\mathrm{A}^{*}$ & $\mathrm{D}$ & I & & & & I & & & & & 152 \\
\hline NPI-2358* & $\mathrm{D}$ & & & & & & & & & increases endothelial permeability & 122 \\
\hline $\begin{array}{l}\text { Vinblastine } \\
\text { (Velban)* }^{*}\end{array}$ & $\mathrm{D}$ & I & I & I & I & I & I & yes & yes & $\begin{array}{l}\text { combines with VEGFR2 } \mathrm{mAb} \text { to inhibit } \\
\text { angiogenesis }\end{array}$ & $\begin{array}{l}104,119 \\
124,132 \\
153-155\end{array}$ \\
\hline $\begin{array}{l}\text { Vincristine } \\
\text { (Oncovin) }^{*}\end{array}$ & $\mathrm{D}$ & I & I & & I & I & & & & increases endothelial permeability & 122,124 \\
\hline Vinflunine & $\mathrm{D}$ & & I & & & I & I & yes & yes & affects EB-1 localization & $156-160$ \\
\hline XRP44X* & $\mathrm{D}$ & & & & I & & & & & inhibits aortal sprouting & 161 \\
\hline
\end{tabular}

$\mathrm{S}=$ Stabilizer; $\mathrm{D}=$ destabilizer I = inhibits; $2-\mathrm{ME}=$ 2-methoxyestradiol.

* In clinical trials (reviewed in Schwartz [103] and Kanthou and Tozer [102]). 
crotubule plus-ends, decreased microtubule targeting to adhesion sites, decreased adhesion site dynamics and the formation of stable stress fibers [157]. These results illustrate that disruption of both plus- and minus-ends of microtubules significantly alters sprouting responses, and cross-talk between microtubules, actin and adhesion complexes is critical to sprouting.

Microtubule stabilizing and destabilizing drugs inhibit HIF- $1 \alpha$ accumulation by disrupting microtubule function [167]. Giannakakou and colleagues [168] first reported that microtubule disruption dysregulates HIF; 2ME2, taxol and vinblastine blocked nuclear accumulation of HIF- $1 \alpha$, VEGF secretion and angiogenic responses. In addition, nuclear HIF- $2 \alpha$ accumulation and VEGF production were blocked in primary endothelial cells [168]. Similar results were observed with M410, which blocked cell cycle progression and induced microtubule depolymerization in a human colon carcinoma line [145]. Stath$\min$ is a cytosolic protein that binds the $\alpha / \beta$-tubulin dimer and depolymerizes microtubules. Stathmin knockdown in primary endothelial cells led to microtubule stabilization and inhibited HIF-1 $\alpha$ protein accumulation and VEGF expression [169]. It appears that 2ME-2, Taxol, vinblastine, M410, ENMD-1198 and epothilone B all reduce HIF- $1 \alpha$ expression, nuclear HIF- $1 \alpha$ accumulation and VEGF expression in endothelial and tumor cells, and these alterations correlate to decreased angiogenic responses in vivo $[145,167,168,170]$. Thus, successful intranuclear transport of HIF appears to require the ability of microtubules to polymerize or depolymerize, as stathmin knockdown and Taxol treatment also block HIF-1 $\alpha$ nuclear translocation $[168,169]$. This action has been linked to the ability of these compounds to target $\beta$-tubulin [167].

\section{Cross-Talk between Microtubules and Actin}

Communication between microtubules, actin and focal adhesions are critical for successful cell motility [171]. Microtubule-binding drugs can alter structures associated with actin assembly, such as adherens junctions and focal adhesions. Both microtubule stabilizing and destabilizing compounds can prevent endothelial focal adhesion formation and assembly [102, 133, 137, 157]. Inhibiting microtubules can cause a loss of cell polarity and block formation of lamellipodia [172]. Consistent with this observation, non-toxic doses of docetaxel, epothilone $B$ and vinblastine significantly inhibited endothelial cell migration, invasion and cord formation on matrigel, which was ascribed to reduced F-actin stress fiber formation, appearance of nuclear F-actin rings and early inhi- bition of Racl and Cdc42 activity [132]. Higher doses of vinblastine, a microtubule-disrupting agent, induced rapid collapse and apoptosis of established endothelial networks in 3-D collagen matrices [153]. Interestingly, inhibiting actin polymerization with cytochalasin $\mathrm{D}$ did not induce collapse of pre-formed 3-D endothelial networks [153]. The vinblastine-induced collapse required Rho GTPases and was blocked with C3 exoenzyme and dominant negative forms of RhoA and RhoC, indicating microtubule depolymerization induced Rho GTPase activation and collapse of endothelial networks [153]. In separate studies, Luis and colleagues [173] recently reported that MVL-PLA2, a phospholipase A2 from snake venom, increased microtubule dynamics and blocked angiogenesis. MVL-PLA2 likewise disrupted focal adhesions, contributing to failed angiogenic responses [173]. In line with this observation, TAE226 inhibition of focal adhesion kinase blocked tube formation in vitro and microvessel density in subcutaneous tumors [174]. These studies underscore the interplay between focal adhesions and dynamic microtubule networks, and illustrate the link between microtubule perturbation and actin regulatory molecules.

Newly forming endothelial cells exhibit a polarized phenotype to guide sprout formation in response to angiogenic stimuli $[74,175,176]$. Crews and colleagues [177] have recently reported the activation of disheveled associated activator of morphogenesis (DAAM1) interferes with endothelial cell division, migration and angiogenesis that correlated with microtubule stabilization. Davis and colleagues [57] have demonstrated that a polarity complex forms with $\mathrm{Cdc} 42$ that guides endothelial cell outgrowth. In line with this, disruption of microtubules may have the added ability to downregulate expression of VEGFR2, but not VEGFR1 [178]. This would be predicted to have a significant impact on angiogenic sprouting because VEGFR2 is enriched in polarized tip cells [77, 179] and is vital for promoting angiogenic responses [180, 181]. Altogether, these data suggest a complicated crosstalk exists between extracellular cues and establishment of cellular polarity, which is ultimately accomplished through rearrangement of cytoskeletal elements.

\section{Intermediate Filaments}

The intermediate filament cytoskeleton connects the plasma membrane to the nucleus and in many cases displays a tight interaction with the nuclear lamina and nuclear cytoskeleton. Intermediate filament proteins were 
classically thought to function solely for mechanical stabilization of cells, but are more recently being recognized as regulators of signal transduction events [182-184]. Because intermediate filaments are resistant to detergent solubilization, they were once predicted to be stationary; however, intermediate filaments engage in various movements that are linked with assembly, disassembly and subcellular organization [185]. Vimentin is a type III intermediate filament that is expressed in cells of mesenchymal origin, including endothelial cells [186]. Thus, vimentin will be the primary focus of the following discussion.

Vimentin intermediate filament networks are highly dynamic [187], and the polymerized filament is formed through the stacking of dimers and tetramers [188-190]. Each monomer contains a central $\alpha$-helical rod domain that is flanked by an $\mathrm{N}$-terminal head and C-terminal tail [191]. Vimentin polymer organization is dependent on the phosphorylation state, because the introduction of a negatively charged phosphate group, predominantly in the head region, frees soluble vimentin from the polymerized network [192-196]. Phosphorylation may reduce the positive charge in the head and tail domain and reduce the propensity for vimentin polymerization [197, 198]. In addition, the N-terminal head domain is cleaved by calpain $[199,200]$. Fragments of vimentin produced by calpain cleavage do not assemble into intermediate filaments [201], and injection of N-terminal vimentin peptides collapsed intermediate filament networks [202]. These studies show that both phosphorylation and cleavage disrupts vimentin polymerization, producing soluble vimentin, which has been previously suggested to function as an intracellular signal transducer [182].

The underlying cell processes controlled by intermediate filaments remain obscure and have not been investigated in detail in endothelial cells or with respect to blood vessel formation, although many studies have revealed important functions for vimentin in smooth muscle cells, fibroblasts and tumor cells. Mild phenotypic alterations were observed in the original report of vimentin-null animals [203], but subsequent studies have identified defects in endothelial barrier function [204] and fibroblast contraction during wound healing [205]. Vimentin-null mice also have cerebellar defects, impaired motor coordination, and purkinje cell necrosis [206]. Of interest here, Eckes et al. [205] reported a lag in granulation tissue formation that has not been investigated further. This anecdotal evidence supports the possibility that vimentin regulates angiogenic sprouting during granulation tissue formation. Santilman et al. [207] have recently reported that vimentin binds caveolin $\left(\mathrm{Tyr}^{14}\right)$ and co-localized with caveolin at the anterior portion of cells extending protrusions through Boyden chambers. Caveolin-1 polarization in 3-D migrating endothelial cells required the phosphorylatable $\mathrm{Tyr}^{14}$ residue of caveolin-1. Immunoelectron microscopy further indicated that caveolin-1 was distributed along cytoskeletal structures in the anterior of transmigrating endothelial cells [208]. A similar polarization of vimentin and $\mathrm{Tyr}^{14}$ caveolin was reported during retinal development in vivo [207], although vimentin fibers seen in 2-D cultures were reported in endothelial cells extending protrusions across Boyden chamber membranes [207]. Vimentin-null mice have reduced corneal neovascularization [209] and hypoxia-induced retinal neovascularization [210]. Whether these effects can be explained by direct defects in endothelial function remains to be demonstrated.

While classically thought to provide mechanical support to cells and tissues, emerging evidence suggests additional roles for intermediate filaments. Peptide-induced disassembly of vimentin intermediate filaments dramatically altered fibroblast shape as well as microfilament and microtubule organization [202], yet, in mice lacking vimentin, cytoskeletal organization is normal [203]. These seemingly conflicting observations suggest that vimentin monomers are signaling intermediates [186]. The mechanical properties of intermediate filaments in vitro and the fact that in most cells they form interacting networks between the cell surface and the nucleus supports the hypothesis that the intermediate filament cytoskeleton provides a scaffold to sense and transduce mechanical signals. For example, applying 12 dynes/ $\mathrm{cm}^{2}$ shear stress to vascular endothelial cells rapidly displaced the extensive 3-D networks of vimentin intermediate filament networks at the apical surface. Intermediate filaments are displaced approximately $1 \mu \mathrm{m}$ in a 3 -min time period. While these movements occurred throughout the cytoplasm, there was relatively more translocation at the apical surface than the basal surface of the cell [211]. The idea that vimentin may act as a mechanotransducer is supported by defective flow-induced vasodilation responses in vimentin-null animals [212]. Recent work by Fainzilber and colleagues [213, 214] also highlights the ability of calpain-cleaved vimentin fragments to act as intracellular chaperones to alter gene transcription following crush injuries. Newly synthesized vimentin was cleaved by calpain and bound to $\mathrm{p} 42$ and p44 mitogen-activated protein kinases (pErk1/2) [213], protecting phosphorylated Erks from dephosphor- 


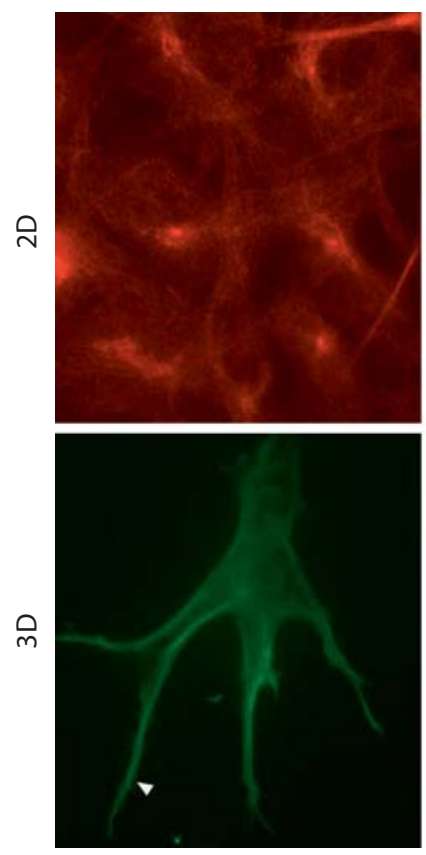

$\alpha$-Tubulin
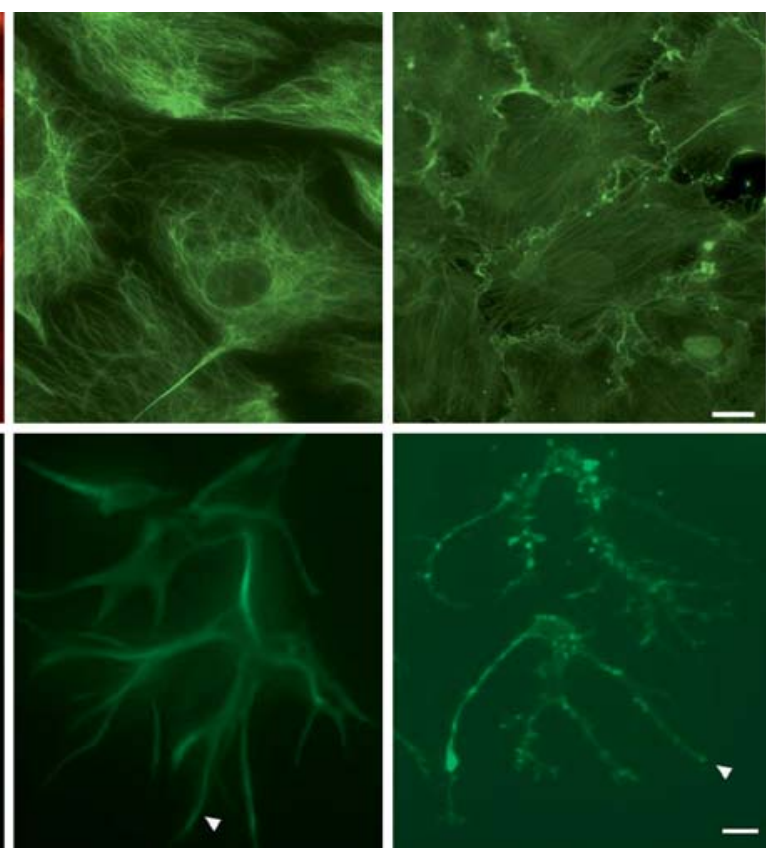

Vimentin

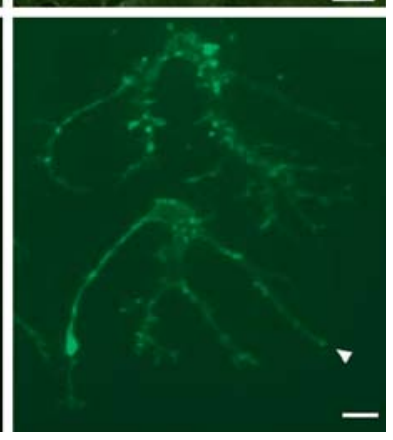

$\alpha-, \beta-, \gamma$-Actin
Fig. 1. Immunofluorescence analysis of tubulin, vimentin and actin arrangement in 2-D versus 3-D cultures. Top row: Human umbilical vein endothelial cells (passage 5) were seeded on $18-\mathrm{mm}$ circular coverslips coated with collagen type I $(20 \mu \mathrm{g} / \mathrm{ml})$ and allowed to attach overnight. Cells were treated with $1 \mu \mathrm{M}$ S1P for $1 \mathrm{~h}$ before being fixed and processed for immunofluorescence as described in the 'Appendix'. Primary antibodies utilized were anti- $\alpha$-tubulin (clone DMA1; Sigma-Aldrich; 1:100), anti-vimentin [V9 FL (p) epitope; Santa Cruz; 1:100] and anti-actin (AB-1 clone JLA20; EMD Biosciences; 1:25). Images were collected with a Nikon Eclipse TE2000-U microscope. $\times 60$. Bottom row: Cells were seeded on 3 -D collagen type I matrices $(2.5 \mathrm{mg} / \mathrm{ml})$ with growth factors and $1 \mu \mathrm{M} \mathrm{S1P}$ for $24 \mathrm{~h}$, fixed in $4 \%$ paraformaldehyde in PBS for $30 \mathrm{~min}$ and processed for immunofluorescence. Images collected with a Zeiss Imager.A1m confocal microscope (0.5- to $1.5-\mu \mathrm{m}$ stacks that were layered into 1 image). $\times 40$. Arrowheads indicate extended peripheral processes. ylation [214] while also transporting them from distal sites of injury to the nucleus to drive transcription. Injured neurons from vimentin-null mice could not perform $\mathrm{pErk} 1 / 2$ transport, and this effect was correlated with delayed recovery of sensation [213]. Thus, soluble non-polymerized vimentin fragments transduced intracellular signals by chaperoning activated Erk $1 / 2$ in regenerating neurons. Finally, treatments that activate signal transduction pathways can change intermediate filament distribution [215]. Given the ability of vimentin to function in signal transduction, it is reasonable to predict that vimentin is involved in initiating angiogenic sprouting responses, although this has not been demonstrated definitively to date. One limitation to thoroughly investigating intermediate filaments is a lack of pharmaceutical compounds that specifically target intermediate filament networks. Withaferin A has been reported to bind vimentin dimers and stabilize vimentin networks [209], and withaferin A has been reported to block tumor angiogen- esis [209, 216, 217]. Although the above-described studies suggest an important function for vimentin in angiogenesis, none to date have defined a mechanism for vimentin regulation of angiogenic network formation. Pilot studies in our laboratory reveal that silencing vimentin expression in primary endothelial cells significantly impairs endothelial sprouting into three-dimensional collagen matrices (data not shown). Further investigation will be required to demonstrate a functional role for the intermediate filament vimentin in orchestrating angiogenic responses and the mechanism through which this occurs.

\section{Cross-Talk between Vimentin and Other Cytoskeletal Elements}

Vimentin is an abundantly expressed protein that associates with various intracellular molecules. Vimentin intermediate filaments are associated with the centrosome [218] and bind activated Rac and Cdc42 [219], phospholipase A2 [220], and the molecular motors kinesin, 


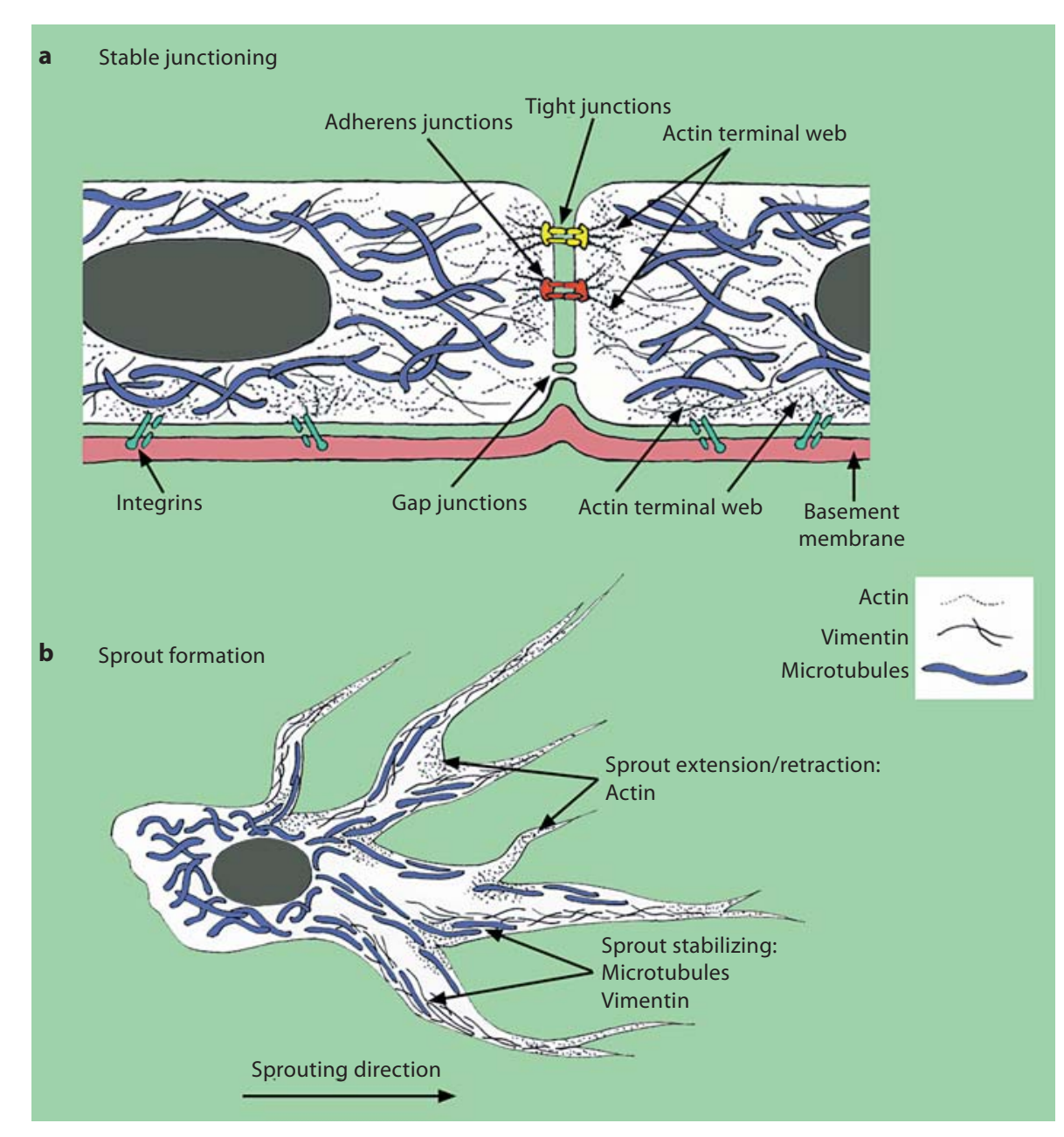

Fig. 2. Schematic depicting microtubule, vimentin and actin localization in quiescent versus activated endothelial cells: quiescent endothelial cells (a) and sprouting endothelial cells (b). Placement is based on the data shown in figure 1 .

dynein and dynactin [221, 222]. Vimentin is important for lipoprotein-derived cholesterol esterification [223]. Interestingly, various protein kinase $\mathrm{C}$ isoforms associate with vimentin intermediate filaments [224-226], and PKC-mediated vimentin phosphorylation regulates recycling of the $\beta 1$-integrin subunit during cell migration [227]. Plectin and intermediate filament associated protein-300 bind and cross-link vimentin to microtubules, microfilaments and membrane adhesion complexes [228-230]. Vimentin associates with filamin A [231], $\alpha$ crystallin [232], cGMP kinase [233] and Yes kinase [234]. The carboxy terminus of vimentin binds actin [235], and detyrosinated tubulin recruits vimentin intermediate filaments to microtubules [236]. Lastly, deleterious effects, including cataracts and lens degeneration, are seen in mice that overexpress vimentin [237]. These data underscore the intricate relationships established by molecules to integrate actin and microtubule dynamics with the vimentin intermediate filament cytoskeleton. Further work will be required to continue to tease apart how the various cytoskeletal moieties interact with one another to control motility and angiogenic sprouting.

\section{Intracellular Localization of Actin, Tubulin and \\ Vimentin during Endothelial Sprouting}

We investigated the distribution of microtubules, vimentin and actin in 2-D versus 3-D endothelial cultures using indirect immunofluorescence (fig. 1). Filamentous networks for $\alpha$-tubulin, vimentin and $\alpha$-, $\beta$-, $\gamma$-actin were seen in 2-D endothelial monolayers that extended from nucleus to plasma membrane (fig. 1, upper panels). The arrangement of these networks was distinct, however, for endothelial cells invading 3-D collagen matrices, which mimics angiogenic sprout initiation. Large highly aligned bundles in 3-D cultures were observed for $\alpha$-tubulin and vimentin that were maintained continuously throughout extensions of peripheral processes. These distinctions are depicted in the schematic in figure 2. The images high- 


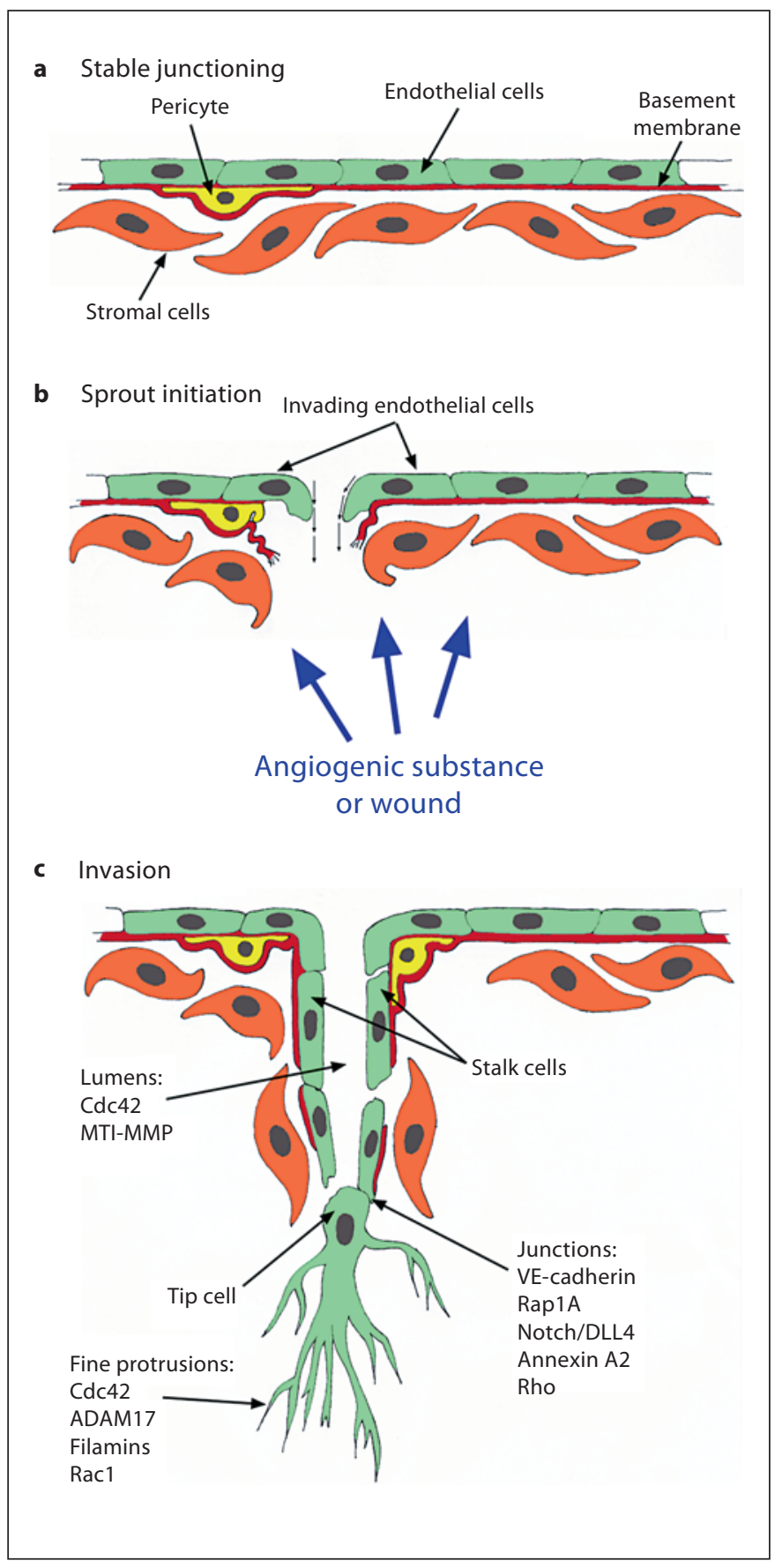

Fig. 3. Schematic illustration illustrating key steps in angiogenesis, along with molecules that transduce signals to the cytoskeleton to induce sprouting angiogenesis. a Quiescent endothelium exhibiting intact basement membrane (red), mural cell (yellow) and intact junctions. b Sprout initiation is stimulated by local production of angiogenic factors, which disrupt junctions and basement membrane integrity to initiate sprouting responses. c Sprout extension and new vessel growth. Key molecules that control lumen formation, junctional signaling and fine protrusion formation are indicated. light key differences in cytoskeletal arrangement in 2-D monolayers (those forming stable junctions) and 3-D invading endothelial cells, which form sprouting structures.

Microtubules are clearly required for maintenance of both 2-D monolayers and endothelial sprouting structures. Treatment with either microtubule-destabilizing or -stabilizing compounds collapses existing structures $([130,142,153]$ and data not shown). Actin arrangement in 3-D, however, was punctuate and distinctive from 2-D arrangements. Actin foci observed in 3-D are established at critical subcellular locations (e.g. strategic branch points). It is possible that fine extended protrusions are more susceptible to collapse because of differences in adherence to the ECM. We have reported that endothelial cells continually extend and retract peripheral processes while advancing through 3-D collagen matrices, and this extension and retraction required a disintegrin and metalloproteinase 17 (ADAM17) [238]. These extended peripheral processes (indicated by arrowheads in fig. 1) often extend around individual collagen fibers, but do not alter collagen density or arrangement significantly [239]. At the same time, extension and retraction of peripheral processes is occurring at the leading edge of the sprout, while individual tunnels are generated by trailing endothelial cells (analogous to stalk cells) which generate the lumen portion of the structure [239-241]. The various states initiated in angiogenesis are depicted in figure 3, where quiescent endothelial cells with stable junctions are activated by release of pro-angiogenic stimuli. This endothelial activation triggers sprout initiation, endothelial invasion and new blood vessel formation.

It appears that cytoskeletal arrangements within endothelial cells extending sprouts into an intact 3-D ECM versus endothelial cells lining and forming a monolayer are distinct, and cellular responses to various cues rely heavily on both matrix integrity and endothelial cell polarization, which would be expected to be distinct at various segments of developing sprouts. Certainly, these interactions are dynamic, as developing microvascular structures alter the mechanical properties of the surrounding ECM with time [239, 242]. The cell-matrix interactions between newly forming angiogenic structures are mediated through integrins [14, 15, 21, 40-43, 243, 244], and maintaining endothelial attachments are dependent on integrin-mediated contacts, because integrin antagonism collapses sprouting structures [21]. In addition, varying the matrix density, which presumably alters the availability of integrin binding sites within the ECM, alters sprouting responses and lumen size in various assays ([245, 246] and our unpublished observations). Although extensive 
studies to date have revealed important clues, the precise molecular cues responsible for the intricate processes of initiating, propelling and maintaining endothelial sprouting structures remain to be definitively identified.

Altogether, the studies described here illustrate a key role for the cytoskeleton in angiogenic sprout initiation and maintenance, which are summarized in figure 3. Continued investigations will clarify how cross-talk between microtubule, microfilament and intermediate filament networks is accomplished for these vital processes. Also of interest is how various cytoskeletal networks integrate with and respond to the key signaling pathways known to regulate angiogenesis. Lastly, continued discovery of new compounds that target cytoskeletal components and normalize aberrant angiogenesis will provide additional tools to combat pathological angiogenesis in disease.

\section{Appendix}

\section{Reagents}

Human umbilical vein endothelial cells were purchased from Lonza and maintained as described [247].

\section{Immunofluorescence Analyses}

Endothelial cells seeded on coverslips were fixed in 2\% paraformaldehyde in PBS for $10 \mathrm{~min}$, rinsed twice with Tris-glycine buffer, permeabilized for 15 min with $0.5 \%$ Triton X-100 in PBS, and blocked overnight in blocking buffer (1\% BSA, $0.2 \%$ sodium azide, $0.1 \%$ TX-100, $1 \%$ goat serum in TBS). Coverslips were washed for 5 min with wash buffer (0.1\% Triton X-100 in PBS). Secondary antibodies (goat anti-mouse, Jackson Immuno Research; 1:60) in blocking buffer were added for $1 \mathrm{~h}$ at room temperature. Samples were washed for $5 \mathrm{~min}$, rinsed in water and mounted. Endothelial cells invading 3-D collagen matrices were allowed to invade for $24 \mathrm{~h}$, fixed in $4 \%$ paraformaldehyde in PBS for $30 \mathrm{~min}$, and rinsed twice with Tris-glycine buffer. Samples were cut to generate a side view, permeabilized for $1 \mathrm{~h}(0.5 \%$ Triton $\mathrm{X}-100$ in PBS), and blocked overnight in blocking buffer (1\% BSA, $0.2 \%$ sodium azide, $0.1 \%$ TX-100, $1 \%$ goat serum in TBS). Primary antibody was added at room temperature for $3 \mathrm{~h}$. Samples were washed for 45 min with wash buffer. Secondary antibodies (goat anti-mouse Alexa Fluor ${ }^{\circledR}$ 488; Molecular Probes) were diluted 1:300 in blocking buffer and incubated at room temperature for $1 \mathrm{~h}$. Samples were washed overnight for the $\alpha$-tubulin and vimentin. Samples stained with actin were washed for $30 \mathrm{~min}$, rinsed in water, and mounted.

\section{Acknowledgments}

This work was supported by NIH R01HL09576, National Research Initiative Competitive Grants No. 2009-35203-05725 from the USDA National Institute of Food and Agriculture, and $\mathrm{Na}-$ tional Research Initiative Competitive Grant No. 2006-3520317199 from the USDA Cooperative State Research, Education, and Extension Service.

We thank Dr. Jeffrey Essner for reading the manuscript and for helpful suggestions. We thank Adriana Mendoza for assistance with immunofluorescence studies.

\section{References}

1 Carmeliet P: Angiogenesis in health and disease. Nat Med 2003;9:653-660.

$\checkmark 2$ Carmeliet P: Manipulating angiogenesis in medicine. J Intern Med 2004;255:538-561.

- 3 Ferrara N, Carver-Moore K, Chen H, Dowd M, Lu L, O'Shea KS, Powell-Braxton L, Hillan KJ, Moore MW: Heterozygous embryonic lethality induced by targeted inactivation of the VEGF gene. Nature 1996;380:439-442.

-4 Fong GH, Rossant J, Gertsenstein M, Breitman ML: Role of the Flt-1 receptor tyrosine kinase in regulating the assembly of vascular endothelium. Nature 1995;376:66-70.

5 Shalaby F, Rossant J, Yamaguchi TP, Gertsenstein M, Wu XF, Breitman ML, Schuh AC: Failure of blood-island formation and vasculogenesis in Flk-1-deficient mice. Nature 1995;376:62-66.

-6 Zebrowski BK, Liu W, Ramirez K, Akagi Y, Mills GB, Ellis LM: Markedly elevated levels of vascular endothelial growth factor in malignant ascites. Ann Surg Oncol 1999;6:373378 .
7 Werner S, Grose R: Regulation of wound healing by growth factors and cytokines. Physiol Rev 2003;83:835-870.

-8 Turner N, Grose R: Fibroblast growth factor signalling: from development to cancer. Nat Rev Cancer 2010;10:116-129.

-9 Presta M, Dell'Era P, Mitola S, Moroni E, Ronca R, Rusnati M: Fibroblast growth factor/fibroblast growth factor receptor system in angiogenesis. Cytokine Growth Factor Rev 2005;16:159-178.

10 English D, Brindley DN, Spiegel S, Garcia JG: Lipid mediators of angiogenesis and the signalling pathways they initiate. Biochim Biophys Acta 2002;1582:228-239.

11 Hla T: Physiological and pathological actions of sphingosine 1-phosphate. Semin Cell Dev Biol 2004; 15:513-520.

-12 Lee OH, Kim YM, Lee YM, Moon EJ, Lee DJ Kim JH, Kim KW, Kwon YG: Sphingosine 1-phosphate induces angiogenesis: its angiogenic action and signaling mechanism in human umbilical vein endothelial cells. Biochem Biophys Res Commun 1999;264:743-750.
13 Spiegel S, Milstien S: Sphingosine-1-phosphate: an enigmatic signalling lipid. Nat Rev Mol Cell Biol 2003;4:397-407.

14 Senger DR, Claffey KP, Benes JE, Perruzzi CA, Sergiou AP, Detmar M: Angiogenesis promoted by vascular endothelial growth factor: regulation through alphalbetal and alpha2beta1 integrins. Proc Natl Acad Sci USA 1997;94:13612-13617.

-15 Senger DR, Perruzzi CA, Streit M, Koteliansky VE, de Fougerolles AR, Detmar M: The alpha(1)beta(1) and alpha(2)beta(1) integrins provide critical support for vascular endothelial growth factor signaling, endothelial cell migration, and tumor angiogenesis. Am J Pathol 2002;160:195-204.

16 Davis GE, Camarillo CW: An alpha 2 beta 1 integrin-dependent pinocytic mechanism involving intracellular vacuole formation and coalescence regulates capillary lumen and tube formation in three-dimensional collagen matrix. Exp Cell Res 1996;224:3951. 
17 Cheresh DA, Smith JW, Cooper HM, Quaranta V: A novel vitronectin receptor integrin (alpha $\mathrm{v}$ beta $\mathrm{x}$ ) is responsible for distinct adhesive properties of carcinoma cells. Cell 1989;57:59-69.

- 18 Brooks PC, Strömblad S, Sanders LC, von Schalscha TL, Aimes RT, Stetler-Stevenson WG, Quigley JP, Cheresh DA: Localization of matrix metalloproteinase MMP-2 to the surface of invasive cells by interaction with integrin alpha v beta 3. Cell 1996;85:683-693.

19 Davis GE, Bayless KJ: An integrin and rho GTPase-dependent pinocytic vacuole mechanism controls capillary lumen formation in collagen and fibrin matrices. Microcirculation 2003;10:27-44.

-20 Varner JA, Emerson DA, Juliano RL: Integrin alpha 5 beta 1 expression negatively regulates cell growth: reversal by attachment to fibronectin. Mol Biol Cell 1995;6:725-740.

-21 Bayless KJ, Salazar R, Davis GE: Rgd-dependent vacuolation and lumen formation observed during endothelial cell morphogenesis in three-dimensional fibrin matrices involves the alpha(v)beta(3) and alpha(5) beta(1) integrins. Am J Pathol 2000;156: 1673-1683.

-22 Bazzoni G, Dejana E: Endothelial cell-to-cell junctions: molecular organization and role in vascular homeostasis. Physiol Rev 2004; 84:869-901.

23 Wallez Y, Huber P: Endothelial adherens and tight junctions in vascular homeostasis, inflammation and angiogenesis. Biochim Biophys Acta 2008;1778:794-809.

-24 Dejana E: Endothelial cell-cell junctions: happy together. Nat Rev Mol Cell Biol 2004; 5:261-270.

-25 van Hinsbergh VW, Koolwijk P: Endothelial sprouting and angiogenesis: matrix metalloproteinases in the lead. Cardiovasc Res 2008; 78:203-212.

-26 Jackson C: Matrix metalloproteinases and angiogenesis. Curr Opin Nephrol Hypertens 2002;11:295-299.

27 Egeblad M, Werb Z: New functions for the matrix metalloproteinases in cancer progression. Nat Rev Cancer 2002;2:161-174.

-28 van Hinsbergh VW, Engelse MA, Quax PH: Pericellular proteases in angiogenesis and vasculogenesis. Arterioscler Thromb Vasc Biol 2006;26:716-728.

29 Handsley MM, Edwards DR: Metalloproteinases and their inhibitors in tumor angiogenesis. Int J Cancer 2005;115:849-860.

- 30 Bach TL, Barsigian C, Chalupowicz DG, Busler D, Yaen CH, Grant DS, Martinez J: VE-Cadherin mediates endothelial cell capillary tube formation in fibrin and collagen gels. Exp Cell Res 1998;238:324-334.

- 31 Liao F, Li Y, O’Connor W, Zanetta L, Bassi R, Santiago A, Overholser J, Hooper A, Mignatti P, Dejana E, Hicklin DJ, Bohlen P: Monoclonal antibody to vascular endothelial-cadherin is a potent inhibitor of angiogenesis, tumor growth, and metastasis. Cancer Res 2000;60:6805-6810.
32 Carmeliet P, Lampugnani MG, Moons L, Breviario F, Compernolle V, Bono F, Balconi G, Spagnuolo R, Oosthuyse B, Dewerchin M, Zanetti A, Angellilo A, Mattot V, Nuyens D, Lutgens E, Clotman F, de Ruiter MC, Gittenberger-de Groot A, Poelmann R, Lupu F, Herbert JM, Collen D, Dejana E: Targeted deficiency or cytosolic truncation of the vecadherin gene in mice impairs VEGF-mediated endothelial survival and angiogenesis. Cell 1999;98:147-157.

33 Yang S, Graham J, Kahn JW, Schwartz EA, Gerritsen ME: Functional roles for PECAM1 (cd31) and VE-cadherin (cd144) in tube assembly and lumen formation in three-dimensional collagen gels. Am J Pathol 1999; 155:887-895.

34 Luo Y, Radice GL: N-cadherin acts upstream of VE-cadherin in controlling vascular morphogenesis. J Cell Biol 2005;169:29-34.

35 Thoenes L, Gunther M: Novel approaches in anti-angiogenic treatment targeting endothelial F-actin: a new anti-angiogenic strategy? Curr Opin Mol Ther 2008;10:579-590.

36 Lamalice L, Le Boeuf F, Huot J: Endothelial cell migration during angiogenesis. Circ Res 2007;100:782-794.

37 Hynes RO, Lively JC, McCarty JH, Taverna D, Francis SE, Hodivala-Dilke K, Xiao Q: The diverse roles of integrins and their ligands in angiogenesis. Cold Spring Harb Symp Quant Biol 2002;67:143-153.

38 London NR, Whitehead KJ, Li DY: Endogenous endothelial cell signaling systems maintain vascular stability. Angiogenesis 2009;12:149-158.

39 Iruela-Arispe ML, Davis GE: Cellular and molecular mechanisms of vascular lumen formation. Dev Cell 2009;16:222-231.

40 Drake CJ, Cheresh DA, Little CD: An antagonist of integrin alpha $\mathrm{v}$ beta 3 prevents maturation of blood vessels during embryonic neovascularization. J Cell Sci 1995;108: 2655-2661.

-41 Drake CJ, Davis LA, Little CD: Antibodies to beta 1-integrins cause alterations of aortic vasculogenesis, in vivo. Dev Dyn 1992;193: 83-91.

-42 Brooks PC, Clark RA, Cheresh DA: Requirement of vascular integrin alpha $\mathrm{v}$ beta 3 for angiogenesis. Science 1994;264:569-571.

43 Perruzzi CA, de Fougerolles AR, Koteliansky VE, Whelan MC, Westlin WF, Senger DR: Functional overlap and cooperativity among alphav and betal integrin subfamilies during skin angiogenesis. J Invest Dermatol 2003; 120:1100-1109.

-44 Pouyssegur J, Volmat V, Lenormand P: Fidelity and spatio-temporal control in MAP kinase (ERKs) signalling. Biochem Pharmacol 2002;64:755-763.

45 Bryan BA, D’Amore PA: What tangled webs they weave: Rho-GTPase control of angiogenesis. Cell Mol Life Sci 2007;64:20532065.
46 Kanda S, Miyata Y, Kanetake H, Smithgall TE: Non-receptor protein-tyrosine kinases as molecular targets for antiangiogenic therapy (review). Int J Mol Med 2007;20:113-121.

47 Somanath PR, Razorenova OV, Chen J, Byzova TV: Akt1 in endothelial cell and angiogenesis. Cell Cycle 2006;5:512-518.

-48 Mahabeleshwar GH, Feng W, Reddy K, Plow EF, Byzova TV: Mechanisms of integrin-vascular endothelial growth factor receptor cross-activation in angiogenesis. Circ Res 2007; 101:570-580

49 Phillips DR, Nannizzi-Alaimo L, Prasad KS: Beta3 tyrosine phosphorylation in alphaIIbbeta3 (platelet membrane GP IIb-IIIa) outside-in integrin signaling. Thromb Haemost 2001;86:246-258

- 50 Bouvard D, Brakebusch C, Gustafsson E, Aszodi A, Bengtsson T, Berna A, Fassler R: Functional consequences of integrin gene mutations in mice. Circ Res 2001;89:211223.

51 Hall A: Rho GTPases and the actin cytoskeleton. Science 1998;279:509-514.

-52 Koh W, Sachidanandam K, Stratman AN, Sacharidou A, Mayo AM, Murphy EA, Cheresh DA, Davis GE: Formation of endothelial lumens requires a coordinated PKCepsilon-, Src-, Pak- and Raf-kinase-dependent signaling cascade downstream of Cdc42 activation. J Cell Sci 2009;122:18121822.

53 Bayless KJ, Davis GE: The Cdc42 and Rac1 GTPases are required for capillary lumen formation in three-dimensional extracellular matrices. J Cell Sci 2002;115:1123-1136.

54 Kamei M, Saunders WB, Bayless KJ, Dye L, Davis GE, Weinstein BM: Endothelial tubes assemble from intracellular vacuoles in vivo. Nature 2006;442:453-456.

55 Hoang MV, Nagy JA, Senger DR: Cdc42-mediated inhibition of GSK-3beta improves angio-architecture and lumen formation during VEGF-driven pathological angiogenesis. Microvasc Res 2011;81:34-43.

56 Hoang MV, Nagy JA, Senger DR: Active Rac1 improves pathological VEGF neovessel architecture and reduces vascular leak: mechanistic similarities with angiopoietin-1. Blood 2011;117:1751-1760.

57 Sacharidou A, Koh W, Stratman AN, Mayo AM, Fisher KE, Davis GE: Endothelial lumen signaling complexes control 3D matrixspecific tubulogenesis through interdependent Cdc42- and MT1-MMP-mediated events. Blood 2010;115:5259-5269.

- 58 Davis GE, Senger DR: Extracellular matrix mediates a molecular balance between vascular morphogenesis and regression. Curr Opin Hematol 2008;15:197-203.

-59 Koh W, Mahan RD, Davis GE: Cdc42- and Racl-mediated endothelial lumen formation requires Pak2, Pak4 and Par3, and PKC-dependent signaling. J Cell Sci 2008;121:9891001. 
-60 Liu Y, Senger DR: Matrix-specific activation of Src and Rho initiates capillary morphogenesis of endothelial cells. Faseb J 2004;18: 457-468.

61 Hoang MV, Whelan MC, Senger DR: Rho activity critically and selectively regulates endothelial cell organization during angiogenesis. Proc Natl Acad Sci USA 2004;101:18741879.

-62 Garnaas MK, Moodie KL, Liu ML, Samant GV, Li K, Marx R, Baraban JM, Horowitz A, Ramchandran R: Syx, a RhoA guanine exchange factor, is essential for angiogenesis in vivo. Circ Res 2008;103:710-716.

-63 Whitehead KJ, Chan AC, Navankasattusas S, Koh W, London NR, Ling J, Mayo AH, Drakos SG, Jones CA, Zhu W, Marchuk DA, Davis GE, Li DY: The cerebral cavernous malformation signaling pathway promotes vascular integrity via rho GTPases. Nat Med 2009;15:177-184.

64 Glading A, Han J, Stockton RA, Ginsberg MH: KRIT-1/CCM1 is a Rapl effector that regulates endothelial cell cell junctions. J Cell Biol 2007; 179:247-254.

65 Glading AJ, Ginsberg MH: Rap1 and its effector KRIT1/CCM1 regulate beta-catenin signaling. Dis Model Mech 2010;3:73-83.

66 Yan J, Li F, Ingram DA, Quilliam LA: Rapla is a key regulator of fibroblast growth factor 2-induced angiogenesis and together with Rap1b controls human endothelial cell functions. Mol Cell Biol 2008;28:5803-5810.

-67 Carmona G, Gottig S, Orlandi A, Scheele J, Bauerle T, Jugold M, Kiessling F, Henschler R, Zeiher AM, Dimmeler S, Chavakis E: Role of the small GTPase Rap1 for integrin activity regulation in endothelial cells and angiogenesis. Blood 2009;113:488-497.

-68 Weis WI, Nelson WJ: Re-solving the cadherin-catenin-actin conundrum. J Biol Chem 2006;281:35593-35597.

69 Huber AH, Weis WI: The structure of the beta-catenin/E-cadherin complex and the molecular basis of diverse ligand recognition by beta-catenin. Cell 2001;105:391-402.

70 Lilien J, Balsamo J: The regulation of cadherin-mediated adhesion by tyrosine phosphorylation/dephosphorylation of betacatenin. Curr Opin Cell Biol 2005;17:459465.

-71 Gory-Faure S, Prandini MH, Pointu H, Roullot V, Pignot-Paintrand I, Vernet M, Huber P: Role of vascular endothelial-cadherin in vascular morphogenesis. Development 1999;126:2093-2102.

72 Dufraine J, Funahashi Y, Kitajewski J: Notch signaling regulates tumor angiogenesis by diverse mechanisms. Oncogene 2008;27: 5132-5137.

73 Holderfield MT, Hughes CC: Crosstalk between vascular endothelial growth factor, notch, and transforming growth factor-beta in vascular morphogenesis. Circ Res 2008; 102:637-652.
74 Sainson RC, Aoto J, Nakatsu MN, Holderfield M, Conn E, Koller E, Hughes CC: Cellautonomous notch signaling regulates endothelial cell branching and proliferation during vascular tubulogenesis. FASEB J 2005; 19: 1027-1029.

75 Taylor KL, Henderson AM, Hughes CC: Notch activation during endothelial cell network formation in vitro targets the basic HLH transcription factor HESR-1 and downregulates VEGFR-2/KDR expression. Microvasc Res 2002;64:372-383.

76 Hellstrom M, Phng LK, Hofmann JJ, Wallgard E, Coultas L, Lindblom P, Alva J, Nilsson AK, Karlsson L, Gaiano N, Yoon K, Rossant J, Iruela-Arispe ML, Kalen M, Gerhardt $\mathrm{H}$, Betsholtz C: Dll4 signalling through Notch1 regulates formation of tip cells during angiogenesis. Nature 2007;445:776-780.

77 Suchting S, Freitas C, le Noble F, Benedito R, Breant C, Duarte A, Eichmann A: The Notch ligand delta-like 4 negatively regulates endothelial tip cell formation and vessel branching. Proc Natl Acad Sci USA 2007;104:32253230 .

78 Siekmann AF, Lawson ND: Notch signalling limits angiogenic cell behaviour in developing zebrafish arteries. Nature 2007;445:781784.

79 Pines MK, Housden BE, Bernard F, Bray SJ, Roper K: The cytolinker pigs is a direct target and a negative regulator of notch signalling. Development 2010;137:913-922.

80 Popovic M, Bella J, Zlatev V, Hodnik V, Anderluh G, Barlow PN, Pintar A, Pongor S: The interaction of Jagged-1 cytoplasmic tail with afadin PDZ domain is local, folding-independent, and tuned by phosphorylation. J Mol Recognit 2010, E-pub ahead of print.

81 Stossel TP, Condeelis J, Cooley L, Hartwig JH, Noegel A, Schleicher M, Shapiro SS: Filamins as integrators of cell mechanics and signalling. Nat Rev Mol Cell Biol 2001;2:138 145.

82 Ohta Y, Suzuki N, Nakamura S, Hartwig JH, Stossel TP: The small GTPase RalA targets filamin to induce filopodia. Proc Natl Acad Sci USA 1999;96:2122-2128.

83 Zhou AX, Hartwig JH, Akyurek LM: Filamins in cell signaling, transcription and organ development. Trends Cell Biol 2010; 20:113-123.

84 Del Valle-Perez B, Martinez VG, Lacasa-Salavert C, Figueras A, Shapiro SS, Takafuta T, Casanovas O, Capella G, Ventura F, Vinals F: Filamin B plays a key role in vascular endothelial growth factor-induced endothelial cell motility through its interaction with Rac-1 and Vav-2. J Biol Chem 2010;285: 10748-10760.

85 Ling Q, Jacovina AT, Deora A, Febbraio M, Simantov R, Silverstein RL, Hempstead B, Mark WH, Hajjar KA: Annexin II regulates fibrin homeostasis and neoangiogenesis in vivo. J Clin Invest 2004;113:38-48.
86 Gerke V, Weber K: Identity of p36k phosphorylated upon Rous sarcoma virus transformation with a protein purified from brush borders; calcium-dependent binding to non-erythroid spectrin and F-actin. EMBO J 1984;3:227-233.

87 Rescher U, Gerke V: Annexins - unique membrane binding proteins with diverse functions. J Cell Sci 2004;117:2631-2639.

88 Gerke V, Moss SE: Annexins: from structure to function. Physiol Rev 2002;82:331-371.

-89 Heyraud S, Jaquinod M, Durmort C, Dambroise E, Concord E, Schaal JP, Huber P, Gulino-Debrac D: Contribution of annexin 2 to the architecture of mature endothelial adherens junctions. Mol Cell Biol 2008;28:16571668.

90 Harder T, Gerke V: The subcellular distribution of early endosomes is affected by the annexin II2p11(2) complex. J Cell Biol 1993; 123:1119-1132.

-91 Knop M, Aareskjold E, Bode G, Gerke V: Rab3D and annexin A2 play a role in regulated secretion of vWF, but not tPA, from endothelial cells. EMBO J 2004;23:2982-2992.

-92 Yamada A, Fujita N, Sato T, Okamoto R, Ooshio T, Hirota T, Morimoto K, Irie K, Takai Y: Requirement of nectin, but not cadherin, for formation of claudin-based tight junctions in annexin Ii-knockdown MDCK cells. Oncogene 2006;25:5085-5102.

$\$ 93$ Su SC, Maxwell SA, Bayless KJ: Annexin 2 regulates endothelial morphogenesis by controlling AKT activation and junctional integrity. J Biol Chem 2010;285:40624-40634.

-94 Lee OH, Kim YM, Lee YM, Moon EJ, Lee DJ, Kim JH, Kim KW, Kwon YG: Sphingosine 1-phosphate induces angiogenesis: its angiogenic action and signaling mechanism in human umbilical vein endothelial cells. Biochem Biophys Res Commun 1999;264:743-750.

95 Fehon RG, McClatchey AI, Bretscher A: Organizing the cell cortex: the role of ERM proteins. Nat Rev Mol Cell Biol 2010;11:276-287.

96 Schwartz-Albiez R, Merling A, Spring H, Moller P, Koretz K: Differential expression of the microspike-associated protein moesin in human tissues. Eur J Cell Biol 1995;67:189198.

-97 Berryman M, Franck Z, Bretscher A: Ezrin is concentrated in the apical microvilli of a wide variety of epithelial cells whereas moesin is found primarily in endothelial cells. J Cell Sci 1993;105:1025-1043.

98 Guo X, Wang L, Chen B, Li Q, Wang J, Zhao $\mathrm{M}, \mathrm{Wu} \mathrm{W}$, Zhu P, Huang X, Huang Q: ERM protein moesin is phosphorylated by advanced glycation end products and modulates endothelial permeability. Am J Physiol Heart Circ Physiol 2009;297:H238-H246.

99 Koss M, Pfeiffer GR 2nd, Wang Y, Thomas ST, Yerukhimovich M, Gaarde WA, Doerschuk CM, Wang Q: Ezrin/radixin/moesin proteins are phosphorylated by TNF-alpha and modulate permeability increases in human pulmonary microvascular endothelial cells. J Immunol 2006;176:1218-1227. 
100 Wang Y, Kaiser MS, Larson JD, Nasevicius A, Clark KJ, Wadman SA, Roberg-Perez SE, Ekker SC, Hackett PB, McGrail M, Essner JJ: Moesin1 and VE-cadherin are required in endothelial cells during in vivo tubulogenesis. Development 2011;137:3119-3128.

101 Strilic B, Kucera T, Eglinger J, Hughes MR, McNagny KM, Tsukita S, Dejana E, Ferrara $\mathrm{N}$, Lammert E: The molecular basis of vascular lumen formation in the developing mouse aorta. Dev Cell 2009;17:505-515.

102 Kanthou C, Tozer GM: Microtubule depolymerizing vascular disrupting agents: Novel therapeutic agents for oncology and other pathologies. Int J Exper Pathol 2009; 90:284-294.

- 103 Schwartz EL: Antivascular actions of microtubule-binding drugs. Clin Cancer Res 2009;15:2594-2601.

104 Vacca A, Iurlaro M, Ribatti D, Minischetti M, Nico B, Ria R, Pellegrino A, Dammacco F: Antiangiogenesis is produced by nontoxic doses of vinblastine. Blood 1999;94: 4143-4155.

105 Merchan JR, Jayaram DR, Supko JG, He X, Bubley GJ, Sukhatme VP: Increased endothelial uptake of paclitaxel as a potential mechanism for its antiangiogenic effects: potentiation by COX-2 inhibition. Int J Cancer 2005;113:490-498.

- 106 Tozer GM, Kanthou C, Parkins CS, Hill SA: The biology of the combretastatins as tumour vascular targeting agents. Int J Exp Pathol 2002;83:21-38.

107 Segreti JA, Polakowski JS, Koch KA, Marsh KC, Bauch JL, Rosenberg SH, Sham HL, Cox BF, Reinhart GA: Tumor selective antivascular effects of the novel antimitotic compound ABT-751: an in vivo rat regional hemodynamic study. Cancer Chemother Pharmacol 2004;54:273-281.

108 Luo Y, Hradil VP, Frost DJ, Rosenberg SH, Gordon GB, Morgan SJ, Gagne GD, Cox BF, Tahir SK, Fox GB: ABT-751, a novel tubulin-binding agent, decreases tumor perfusion and disrupts tumor vasculature. Anticancer Drugs 2009;20:483-492.

-109 Micheletti G, Poli M, Borsotti P, Martinelli M, Imberti B, Taraboletti G, Giavazzi R: Vascular-targeting activity of zd6126, a novel tubulin-binding agent. Cancer Res 2003;63:1534-1537.

- 110 Davis PD, Dougherty GJ, Blakey DC, Galbraith SM, Tozer GM, Holder AL, Naylor MA, Nolan J, Stratford MR, Chaplin DJ, Hill SA: ZD6126: a novel vascular-targeting agent that causes selective destruction of tumor vasculature. Cancer Res 2002;62:7247-7253.

-111 Blakey DC, Ashton SE, Westwood FR, Walker M, Ryan AJ: ZD6126: a novel small molecule vascular targeting agent. Int J Radiat Oncol Biol Phys 2002;54:1497-1502.

- 112 Blakey DC, Westwood FR, Walker M, Hughes GD, Davis PD, Ashton SE, Ryan AJ: Antitumor activity of the novel vascular targeting agent ZD6126 in a panel of tumor models. Clin Cancer Res 2002;8:1974-1983.
113 Pourgholami MH, Cai ZY, Wang L, Badar S, Links M, Morris DL: Inhibition of cell proliferation, vascular endothelial growth factor and tumor growth by albendazole. Cancer Invest 2009;27:171-177.

114 Pourgholami MH, Yan Cai Z, Lu Y, Wang L, Morris DL: Albendazole: a potent inhibitor of vascular endothelial growth factor and malignant ascites formation in OVCAR-3 tumor-bearing nude mice. Clin Cancer Res 2006;12:1928-1935.

115 van Wijngaarden J, Snoeks TJ, van Beek E, Bloys H, Kaijzel EL, van Hinsbergh VW, Löwik CW: An in vitro model that can distinguish between effects on angiogenesis and on established vasculature: actions of TNP-470, marimastat and the tubulinbinding agent Ang-510. Biochem Biophys Res Commun 2010;39:1161-1165.

116 Delmonte A, Sessa C: Ave8062: a new combretastatin derivative vascular disrupting agent. Expert Opin Investig Drugs 2009;18: 1541-1548.

117 Hori K, Saito S: Microvascular mechanisms by which the combretastatin A-4 derivative AC7700 (AVE8062) induces tumour blood flow stasis. Br J Cancer 2003;89:1334-1344.

118 Hori K, Saito S, Nihei Y, Suzuki M, Sato Y: Antitumor effects due to irreversible stoppage of tumor tissue blood flow: evaluation of a novel combretastatin A-4 derivative, AC7700. Jpn J Cancer Res 1999;90:10261038.

119 Nihei Y, Suga Y, Morinaga Y, Ohishi K, Okano A, Ohsumi K, Hatanaka T, Nakagawa R, Tsuji T, Akiyama Y, Saito S, Hori K, Sato Y, Tsuruo T: A novel combretastatin A-4 derivative, AC-7700, shows marked antitumor activity against advanced solid tumors and orthotopically transplanted tumors. Jpn J Cancer Res 1999;90:1016-1025.

120 Kim TJ, Ravoori M, Landen CN, Kamat AA, Han LY, Lu C, Lin YG, Merritt WM, Jennings N, Spannuth WA, Langley R, Gershenson DM, Coleman RL, Kundra V, Sood AK: Antitumor and antivascular effects of AVE8062 in ovarian carcinoma. Cancer Res 2007;67:9337-9345.

121 Grant DS, Lelkes PI, Fukuda K, Kleinman $\mathrm{HK}$ : Intracellular mechanisms involved in basement membrane induced blood vessel differentiation in vitro. In Vitro Cell Dev Biol 1991;27A:327-336.

122 Nicholson B, Lloyd GK, Miller BR, Palladino MA, Kiso Y, Hayashi Y, Neuteboom ST: Npi-2358 is a tubulin-depolymerizing agent: in-vitro evidence for activity as a tumor vascular-disrupting agent. Anticancer Drugs 2006;17:25-31.

123 Stafford SJ, Schwimer J, Anthony CT, Thomson JL, Wang YZ, Woltering EA: Colchicine and 2-methoxyestradiol inhibit human angiogenesis. J Surg Res 2005; 125: 104-108.
124 Mabeta P, Pepper MS: A comparative study on the anti-angiogenic effects of DNAdamaging and cytoskeletal-disrupting agents. Angiogenesis 2009;12:81-90.

-125 Dachs GU, Steele AJ, Coralli C, Kanthou C, Brooks AC, Gunningham SP, Currie MJ, Watson AI, Robinson BA, Tozer GM: Antivascular agent combretastatin A-4-P modulates hypoxia inducible factor- 1 and gene expression. BMC Cancer 2006;6:280.

-126 Dark GG, Hill SA, Prise VE, Tozer GM, Pettit GR, Chaplin DJ: Combretastatin A-4, an agent that displays potent and selective toxicity toward tumor vasculature. Cancer Res 1997;57:1829-1834.

127 Grosios K, Holwell SE, McGown AT, Pettit GR, Bibby MC: In vivo and in vitro evaluation of combretastatin A-4 and its sodium phosphate prodrug. Br J Cancer 1999;81: 1318-1327.

128 Tozer GM: Measuring tumour vascular response to antivascular and antiangiogenic drugs. Br J Radiol 2003;76(Spec No. 1):S23S35.

129 Tozer GM, Prise VE, Wilson J, Cemazar M, Shan S, Dewhirst MW, Barber PR, Vojnovic B, Chaplin DJ: Mechanisms associated with tumor vascular shut-down induced by combretastatin A-4 phosphate: Intravital microscopy and measurement of vascular permeability. Cancer Res 2001;61:64136422.

$>130$ Vincent L, Kermani P, Young LM, Cheng J, Zhang F, Shido K, Lam G, Bompais-Vincent H, Zhu Z, Hicklin DJ, Bohlen P, Chaplin DJ, May C, Rafii S: Combretastatin A4 phosphate induces rapid regression of tumor neovessels and growth through interference with vascular endothelial-cadherin signaling. J Clin Invest 2005;115:29923006.

131 Burns CJ, Fantino E, Phillips ID, Su S, Harte MF, Bukczynska PE, Frazzetto M, Joffe M, Kruszelnicki I, Wang B, Wang Y, Wilson N, Dilley RJ, Wan SS, Charman SA, Shackleford DM, Fida R, Malcontenti-Wilson C, Wilks AF: Cyt997: a novel orally active tubulin polymerization inhibitor with potent cytotoxic and vascular disrupting activity in vitro and in vivo. Mol Cancer Ther 2009;8:3036-3045.

-132 Bijman MN, van Nieuw Amerongen GP, Laurens N, van Hinsbergh VW, Boven E: Microtubule-targeting agents inhibit angiogenesis at subtoxic concentrations, a process associated with inhibition of Rac1 and Cdc42 activity and changes in the endothelial cytoskeleton. Mol Cancer Ther 2006;5:2348-2357.

$133 \mathrm{Lu} \mathrm{H}$, Murtagh J, Schwartz EL: The microtubule binding drug laulimalide inhibits vascular endothelial growth factor-induced human endothelial cell migration and is synergistic when combined with docetaxel (taxotere). Mol Pharmacol 2006; 69:1207-1215 
134 Sweeney CJ, Miller KD, Sissons SE, Nozaki S, Heilman DK, Shen J, Sledge GW Jr: The antiangiogenic property of docetaxel is synergistic with a recombinant humanized monoclonal antibody against vascular endothelial growth factor or 2-methoxyestradiol but antagonized by endothelial growth factors. Cancer Res 2001;61:3369-3372.

135 Vacca A, Ribatti D, Iurlaro M, Merchionne F, Nico B, Ria R, Dammacco F: Docetaxel versus paclitaxel for antiangiogenesis. J Hematother Stem Cell Res 2002;11:103-118.

136 Hotchkiss KA, Ashton AW, Mahmood R, Russell RG, Sparano JA, Schwartz EL: Inhibition of endothelial cell function in vitro and angiogenesis in vivo by docetaxel (taxotere): association with impaired repositioning of the microtubule organizing center. Mol Cancer Ther 2002;1:1191-1200.

137 Murtagh J, Lu H, Schwartz EL: Taxotereinduced inhibition of human endothelial cell migration is a result of heat shock protein 90 degradation. Cancer Res 2006;66: 8192-8199.

138 Jung HJ, Shim JS, Lee HB, Kim CJ, Kuwano T, Ono M, Kwon HJ: Embellistatin, a microtubule polymerization inhibitor, inhibits angiogenesis both in vitro and in vivo. Biochem Biophys Res Commun 2007;353:376380.

139 Stalder MW, Anthony CT, Woltering EA: Metronomic dosing enhances the anti-angiogenic effect of epothilone B. J Surg Res 2009.

- 140 Petrangolini G, Cassinelli G, Pratesi G, Tortoreto M, Favini E, Supino R, Lanzi C, Belluco S, Zunino F: Antitumour and antiangiogenic effects of IDN 5390, a novel Cseco taxane, in a paclitaxel-resistant human ovarian tumour xenograft. Br J Cancer 2004;90:1464-1468.

141 Taraboletti G, Micheletti G, Rieppi M, Poli M, Turatto M, Rossi C, Borsotti P, Roccabianca P, Scanziani E, Nicoletti MI, Bombardelli E, Morazzoni P, Riva A, Giavazzi R: Antiangiogenic and antitumor activity of IDN 5390, a new taxane derivative. Clin Cancer Res 2002;8:1182-1188.

- 142 Dalyot-Herman N, Delgado-Lopez F, Gewirtz DA, Gupton JT, Schwartz EL: Interference with endothelial cell function by JG-03-14, an agent that binds to the colchicine site on microtubules. Biochem Pharmacol 2009;78:1167-1177.

- 143 Pryor DE, O’Brate A, Bilcer G, Diaz JF, Wang Y, Wang Y, Kabaki M, Jung MK, Andreu JM, Ghosh AK, Giannakakou P, Hamel E: The microtubule stabilizing agent laulimalide does not bind in the taxoid site, kills cells resistant to paclitaxel and epothilones, and may not require its epoxide moiety for activity. Biochemistry 2002;41:9109-9115.

- 144 Mulzer J, Ohler E: Microtubule-stabilizing marine metabolite laulimalide and its derivatives: synthetic approaches and antitumor activity. Chem Rev 2003;103:37533786.
145 Cai YC, Zou Y, Ye YL, Sun HY, Su QG, Wang ZX, Zeng ZL, Xian LJ: Anti-tumor activity and mechanisms of a novel vascular disrupting agent, (z)-3,4',5-trimethoxylstilbene- $3^{\prime}$-o-phosphate disodium (m410). Invest New Drugs 2011;29:300-311.

146 Fotsis T, Zhang Y, Pepper MS, Adlercreutz $\mathrm{H}$, Montesano R, Nawroth PP, Schweigerer L: The endogenous oestrogen metabolite 2-methoxyoestradiol inhibits angiogenesis and suppresses tumour growth. Nature 1994;368:237-239.

147 Klauber N, Parangi S, Flynn E, Hamel E, D'Amato RJ: Inhibition of angiogenesis and breast cancer in mice by the microtubule inhibitors 2-methoxyestradiol and taxol. Cancer Res 1997;57:81-86.

148 Belotti D, Vergani V, Drudis T, Borsotti P, Pitelli MR, Viale G, Giavazzi R, Taraboletti G: The microtubule-affecting drug paclitaxel has antiangiogenic activity. Clin Cancer Res 1996;2:1843-1849.

- 149 Lau DH, Xue L, Young LJ, Burke PA, Cheung AT: Paclitaxel (taxol): an inhibitor of angiogenesis in a highly vascularized transgenic breast cancer. Cancer Biother Radiopharm 1999;14:31-36.

150 Rothmeier AS, Ischenko I, Joore J, Garczarczyk D, Furst R, Bruns CJ, Vollmar AM, Zahler S: Investigation of the marine compound spongistatin 1 links the inhibition of pkcalpha translocation to nonmitotic effects of tubulin antagonism in angiogenesis. FASEB J 2009;23:1127-1137.

151 Meng F, Cai X, Duan J, Matteucci MG, Hart CP: A novel class of tubulin inhibitors that exhibit potent antiproliferation and in vitro vessel-disrupting activity. Cancer Chemother Pharmacol 2008;61:953-963.

152 Kaur G, Hollingshead M, Holbeck S, Schauer-Vukasinovic V, Camalier RF, Domling A, Agarwal S: Biological evaluation of tubulysin A: a potential anticancer and antiangiogenic natural product. Biochem J 2006;396:235-242.

153 Bayless KJ, Davis GE: Microtubule depolymerization rapidly collapses capillary tube networks in vitro and angiogenic vessels in vivo through the small GTPase rho. J Biol Chem 2004;279:11686-11695.

154 Albertsson P, Lennernas B, Norrby K: Dose effects of continuous vinblastine chemotherapy on mammalian angiogenesis mediated by VEGF-A. Acta Oncol 2008;47:293-300.

155 Ribatti D, Guidolin D, Conconi MT, Nico B, Baiguera S, Parnigotto PP, Vacca A, Nussdorfer GG: Vinblastine inhibits the angiogenic response induced by adrenomedullin in vitro and in vivo. Oncogene 2003;22: 6458-6461.

156 Holwell SE, Hill BT, Bibby MC: Anti-vascular effects of vinflunine in the MAC 15A transplantable adenocarcinoma model. $\mathrm{Br} \mathrm{J}$ Cancer 2001;84:290-295.

157 Honore S, Pagano A, Gauthier G, Bourgarel-Rey V, Verdier-Pinard P, Civiletti K, Kruczynski A, Braguer D: Antiangiogenic vinflunine affects EB1 localization and microtubule targeting to adhesion sites. Mol Cancer Ther 2008;7:2080-2089.

158 Kruczynski A, Poli M, Dossi R, Chazottes E, Berrichon G, Ricome C, Giavazzi R, Hill BT, Taraboletti G: Anti-angiogenic, vascular-disrupting and anti-metastatic activities of vinflunine, the latest vinca alkaloid in clinical development. Eur J Cancer 2006; 42:2821-2832.

159 Pourroy B, Honore S, Pasquier E, Bourgarel-Rey V, Kruczynski A, Briand C, Braguer D: Antiangiogenic concentrations of vinflunine increase the interphase microtubule dynamics and decrease the motility of endothelial cells. Cancer Res 2006; 66:3256-3263.

160 Klement G, Baruchel S, Rak J, Man S, Clark K, Hicklin DJ, Bohlen P, Kerbel RS: Continuous low-dose therapy with vinblastine and VEGF receptor-2 antibody induces sustained tumor regression without overt toxicity. J Clin Invest 2000;105:R15-R24.

161 Wasylyk C, Zheng H, Castell C, Debussche L, Multon MC, Wasylyk B: Inhibition of the Ras-Net (Elk-3) pathway by a novel pyrazole that affects microtubules. Cancer Res 2008;68:1275-1283.

162 Jordan MA, Wilson L: Microtubules and actin filaments: dynamic targets for cancer chemotherapy. Curr Opin Cell Biol 1998; 10:123-130.

163 Giannakakou P, Sackett D, Fojo T: Tubulin/ microtubules: still a promising target for new chemotherapeutic agents. J Natl Cancer Inst 2000;92:182-183.

164 Bouckson-Castaing V, Moudjou M, Ferguson DJ, Mucklow S, Belkaid Y, Milon G, Crocker PR: Molecular characterisation of ninein, a new coiled-coil protein of the centrosome. J Cell Sci 1996;109:179-190.

165 Mogensen MM, Malik A, Piel M, Bouckson-Castaing V, Bornens M: Microtubule minus-end anchorage at centrosomal and non-centrosomal sites: the role of ninein. J Cell Sci 2000;113:3013-3023.

166 Matsumoto T, Schiller P, Dieterich LC, Bahram F, Iribe Y, Hellman U, Wikner C, Chan G, Claesson-Welsh L, Dimberg A: Ninein is expressed in the cytoplasm of angiogenic tip-cells and regulates tubular morphogenesis of endothelial cells. Arterioscler Thromb Vasc Biol 2008;28:21232130.

167 Escuin D, Kline ER, Giannakakou P: Both microtubule-stabilizing and microtubuledestabilizing drugs inhibit hypoxia-inducible factor-1alpha accumulation and activity by disrupting microtubule function. Cancer Res 2005;65:9021-9028.

168 Mabjeesh NJ, Escuin D, LaVallee TM, Pribluda VS, Swartz GM, Johnson MS, Willard MT, Zhong H, Simons JW, Giannakakou P: 2ME2 inhibits tumor growth and angiogenesis by disrupting microtubules and dysregulating HIF. Cancer Cell 2003;3: 363-375. 
169 Yoshie M, Miyajima E, Kyo S, Tamura K: Stathmin, a microtubule regulatory protein, is associated with hypoxia-inducible factor-1alpha levels in human endometrial and endothelial cells. Endocrinology 2009; 150:2413-2418.

-170 Moser C, Lang SA, Mori A, Hellerbrand C, Schlitt HJ, Geissler EK, Fogler WE, Stoeltzing O: ENMD-1198, a novel tubulinbinding agent reduces HIF-1alpha and STAT3 activity in human hepatocellular carcinoma(HCC) cells, and inhibits growth and vascularization in vivo. BMC Cancer 2008;8:206.

171 Ballestrem C, Magid N, Zonis J, Shtutman $\mathrm{M}$, Bershadsky A: Interplay between the Actin Cytoskeleton, Focal Adhesions, and Microtubules. New York, John Wiley and Sons, 2004, pp 75-99.

- 172 Liao G, Nagasaki T, Gundersen GG: Low concentrations of nocodazole interfere with fibroblast locomotion without significantly affecting microtubule level: implications for the role of dynamic microtubules in cell locomotion. J Cell Sci 1995;108: 3473-3483.

173 Bazaa A, Pasquier E, Defilles C, Limam I, Kessentini-Zouari R, Kallech-Ziri O, El Battari A, Braguer D, El Ayeb M, Marrakchi N, Luis J: MVL-PLA2, a snake venom phospholipase A2, inhibits angiogenesis through an increase in microtubule dynamics and disorganization of focal adhesions. PLoS One 2010;5:e10124.

-174 Schultze A, Decker S, Otten J, Horst AK, Vohwinkel G, Schuch G, Bokemeyer C, Loges S, Fiedler W: Tae226-mediated inhibition of focal adhesion kinase interferes with tumor angiogenesis and vasculogenesis. Invest New Drugs 2010;28:825-833.

-175 Cirone P, Lin S, Griesbach HL, Zhang Y, Slusarski DC, Crews CM: A role for planar cell polarity signaling in angiogenesis. Angiogenesis 2008;11:347-360.

-176 Montesano R, Orci L, Vassalli P: In vitro rapid organization of endothelial cells into capillary-like networks is promoted by collagen matrices. J Cell Biol 1983;97:1648-1652.

177 Ju R, Cirone P, Lin S, Griesbach H, Slusarski DC, Crews CM: Activation of the planar cell polarity formin DAAM1 leads to inhibition of endothelial cell proliferation, migration, and angiogenesis. Proc Natl Acad Sci USA;107:6906-6911.

-178 Meissner M, Pinter A, Michailidou D, Hirgovic I, Kaprolat N, Stein M, Holtmeier W, Kaufmann R, Gille J: Microtubule-targeted drugs inhibit VEGF receptor-2 expression by both transcriptional and post-transcriptional mechanisms. J Invest Dermatol 2008; 128:2084-2091.

-179 Gerhardt H, Golding M, Fruttiger M, Ruhrberg C, Lundkvist A, Abramsson A, Jeltsch M, Mitchell C, Alitalo K, Shima D, Betsholtz C: VEGF guides angiogenic sprouting utilizing endothelial tip cell filopodia. J Cell Biol 2003;161:1163-1177.
180 Gerhardt H, Betsholtz C: How do endothe lial cells orientate? EXS 2005;94:3-15.

181 Witte L, Hicklin DJ, Zhu Z, Pytowski B, Kotanides H, Rockwell P, Bohlen P: Monoclonal antibodies targeting the VEGF receptor-2 (Flk1/KDR) as an anti-angiogenic therapeutic strategy. Cancer Metastasis Rev 1998;17:155-161.

182 Paramio JM, Jorcano JL: Beyond structure: do intermediate filaments modulate cell signalling? Bioessays 2002;24:836-844.

183 Ivaska J, Pallari HM, Nevo J, Eriksson JE: Novel functions of vimentin in cell adhesion, migration, and signaling. Exp Cell Res 2007;313:2050-2062.

184 Chou YH, Flitney FW, Chang L, Mendez M, Grin B, Goldman RD: The motility and dynamic properties of intermediate filaments and their constituent proteins. Exp Cell Res 2007;313:2236-2243

185 Helfand BT, Chang L, Goldman RD: Intermediate filaments are dynamic and motile elements of cellular architecture. J Cell Sci 2004;117:133-141.

186 Evans RM: Vimentin: The conundrum of the intermediate filament gene family. Bioessays 1998;20:79-86.

187 Yoon M, Moir RD, Prahlad V, Goldman RD: Motile properties of vimentin intermediate filament networks in living cells. J Cell Biol 1998;143:147-157.

188 Fuchs E, Weber K: Intermediate filaments: structure, dynamics, function, and disease. Annu Rev Biochem 1994;63:345-382.

189 Herrmann H, Aebi U: Intermediate filaments: molecular structure, assembly mechanism, and integration into functionally distinct intracellular scaffolds. Annu Rev Biochem 2004;73:749-789.

190 Herrmann H, Bar H, Kreplak L, Strelkov SV, Aebi U: Intermediate filaments: from cell architecture to nanomechanics. Nat Rev Mol Cell Biol 2007;8:562-573.

191 Herrmann H, Aebi U: Structure, assembly, and dynamics of intermediate filaments. Subcell Biochem 1998;31:319-362.

-192 Eriksson JE, He T, Trejo-Skalli AV, Harmala-Brasken AS, Hellman J, Chou YH, Goldman RD: Specific in vivo phosphorylation sites determine the assembly dynamics of vimentin intermediate filaments. J Cell Sci 2004;117:919-932.

193 Inagaki M, Nishi Y, Nishizawa K, Matsuyama M, Sato C: Site-specific phosphorylation induces disassembly of vimentin filaments in vitro. Nature 1987;328:649-652.

194 Inagaki N, Tsujimura K, Tanaka J, Sekimata M, Kamei Y, Inagaki M: Visualization of protein kinase activities in single cells by antibodies against phosphorylated vimentin and GFAP. Neurochem Res 1996;21: 795-800.

195 Izawa I, Inagaki M: Regulatory mechanisms and functions of intermediate filaments: a study using site- and phosphorylation state-specific antibodies. Cancer Sci 2006;97:167-174.
196 Inagaki M, Takahara H, Nishi Y, Sugawara $\mathrm{K}$, Sato $\mathrm{C}$ : $\mathrm{Ca}^{2+}$-dependent deiminationinduced disassembly of intermediate filaments involves specific modification of the amino-terminal head domain. J Biol Chem 1989;264:18119-18127.

197 Traub P, Scherbarth A, Wiegers W, Shoeman RL: Salt-stable interaction of the amino-terminal head region of vimentin with the alpha-helical rod domain of cytoplasmic intermediate filament proteins and its relevance to protofilament structure and filament formation and stability. J Cell Sci 1992;101:363-381.

$>198$ Kaufmann E, Weber K, Geisler N: Intermediate filament forming ability of desmin derivatives lacking either the amino-terminal 67 or the carboxy-terminal 27 residues. J Mol Biol 1985;185:733-742.

199 Fischer S, Vandekerckhove J, Ampe C, Traub P, Weber K: Protein-chemical identification of the major cleavage sites of the $\mathrm{Ca}^{2+}$ proteinase on murine vimentin, the mesenchymal intermediate filament protein. Biol Chem Hoppe Seyler 1986;367: 1147-1152.

200 Tompa P, Buzder-Lantos P, Tantos A, Farkas A, Szilagyi A, Banoczi Z, Hudecz F, Friedrich P: On the sequential determinants of calpain cleavage. J Biol Chem 2004; 279:20775-20785.

201 Traub P, Vorgias CE: Involvement of the Nterminal polypeptide of vimentin in the formation of intermediate filaments. J Cell Sci 1983;63:43-67.

202 Goldman RD, Khuon S, Chou YH, Opal P, Steinert PM: The function of intermediate filaments in cell shape and cytoskeletal integrity. J Cell Biol 1996;134:971-983.

203 Colucci-Guyon E, Portier MM, Dunia I, Paulin D, Pournin S, Babinet C: Mice lacking vimentin develop and reproduce without an obvious phenotype. Cell 1994;79: 679-694.

204 Nieminen M, Henttinen T, Merinen M, Marttila-Ichihara F, Eriksson JE, Jalkanen S: Vimentin function in lymphocyte adhesion and transcellular migration. Nat Cell Biol 2006;8:156-162.

205 Eckes B, Colucci-Guyon E, Smola H, Nodder S, Babinet C, Krieg T, Martin P: Impaired wound healing in embryonic and adult mice lacking vimentin. J Cell Sci 2000;113:2455-2462.

206 Colucci-Guyon E, Gimenez Y Ribotta M, Maurice T, Babinet C, Privat A: Cerebellar defect and impaired motor coordination in mice lacking vimentin. Glia 1999;25:33-43.

207 Santilman V, Baran J, Anand-Apte B, Evans RM, Parat MO: Caveolin-1 polarization in transmigrating endothelial cells requires binding to intermediate filaments. Angiogenesis 2007;10:297-305.

-208 Parat MO, Anand-Apte B, Fox PL: Differential caveolin-1 polarization in endothelial cells during migration in two and three dimensions. Mol Biol Cell 2003;14:3156-3168. 
-209 Bargagna-Mohan P, Hamza A, Kim YE, Khuan Abby Ho Y, Mor-Vaknin N, Wendschlag N, Liu J, Evans RM, Markovitz DM, Zhan CG, Kim KB, Mohan R: The tumor inhibitor and antiangiogenic agent withaferin a targets the intermediate filament protein vimentin. Chem Biol 2007;14:623634.

-210 Lundkvist A, Reichenbach A, Betsholtz C, Carmeliet P, Wolburg H, Pekny M: Under stress, the absence of intermediate filaments from Muller cells in the retina has structural and functional consequences. J Cell Sci 2004;117:3481-3488.

-211 Helmke BP, Goldman RD, Davies PF: Rapid displacement of vimentin intermediate filaments in living endothelial cells exposed to flow. Circ Res 2000;86:745-752.

-212 Henrion D, Terzi F, Matrougui K, Duriez M, Boulanger CM, Colucci-Guyon E, Babinet C, Briand P, Friedlander G, Poitevin P, Levy BI: Impaired flow-induced dilation in mesenteric resistance arteries from mice lacking vimentin. J Clin Invest 1997;100: 2909-2914.

-213 Perlson E, Hanz S, Ben-Yaakov K, SegalRuder Y, Seger R, Fainzilber M: Vimentindependent spatial translocation of an activated map kinase in injured nerve. Neuron 2005;45:715-726.

-214 Perlson E, Michaelevski I, Kowalsman N, Ben-Yaakov K, Shaked M, Seger R, Eisenstein M, Fainzilber M: Vimentin binding to phosphorylated Erk sterically hinders enzymatic dephosphorylation of the kinase. J Mol Biol 2006;364:938-944.

-215 Chang L, Goldman RD: Intermediate filaments mediate cytoskeletal crosstalk. Nat Rev Mol Cell Biol 2004;5:601-613.

-216 Lahat G, Zhu QS, Huang KL, Wang S, Bolshakov S, Liu J, Torres K, Langley RR, Lazar AJ, Hung MC, Lev D: Vimentin is a novel anti-cancer therapeutic target; insights from in vitro and in vivo mice xenograft studies. PLoS One 2010;5:e10105.

-217 Mohan R, Hammers HJ, Bargagna-Mohan P, Zhan XH, Herbstritt CJ, Ruiz A, Zhang L, Hanson AD, Conner BP, Rougas J, Pribluda VS: Withaferin a is a potent inhibitor of angiogenesis. Angiogenesis 2004;7: $115-122$.

-218 Trevor KT, McGuire JG, Leonova EV: Association of vimentin intermediate filaments with the centrosome. J Cell Sci 1995; 108:343-356.

-219 Meriane M, Mary S, Comunale F, Vignal E, Fort P, Gauthier-Rouviere C: Cdc42hs and Racl GTPases induce the collapse of the vimentin intermediate filament network. J Biol Chem 2000;275:33046-33052.

-220 Nakatani Y, Tanioka T, Sunaga S, Murakami M, Kudo I: Identification of a cellular protein that functionally interacts with the C2 domain of cytosolic phospholipase A(2)alpha. J Biol Chem 2000;275: 1161-1168.
221 Prahlad V, Yoon M, Moir RD, Vale RD, Goldman RD: Rapid movements of vimentin on microtubule tracks: kinesin-dependent assembly of intermediate filament networks. J Cell Biol 1998;143:159-170.

222 Helfand BT, Mikami A, Vallee RB, Goldman RD: A requirement for cytoplasmic dynein and dynactin in intermediate filament network assembly and organization. J Cell Biol 2002;157:795-806.

223 Sarria AJ, Panini SR, Evans RM: A functional role for vimentin intermediate filaments in the metabolism of lipoprotein-derived cholesterol in human SW-13 cells. J Biol Chem 1992;267:19455-19463.

224 Murti KG, Kaur K, Goorha RM: Protein kinase $\mathrm{C}$ associates with intermediate filaments and stress fibers. Exp Cell Res 1992; 202:36-44.

225 Spudich A, Meyer T, Stryer L: Association of the beta isoform of protein kinase $\mathrm{C}$ with vimentin filaments. Cell Motil Cytoskeleton 1992;22:250-256.

226 Owen PJ, Johnson GD, Lord JM: Protein kinase C-delta associates with vimentin intermediate filaments in differentiated HL60 cells. Exp Cell Res 1996;225:366-373.

227 Ivaska J, Vuoriluoto K, Huovinen T, Izawa I, Inagaki M, Parker PJ: Pkcepsilon-mediated phosphorylation of vimentin controls integrin recycling and motility. Embo J 2005;24:3834-3845.

228 Spurny R, Gregor M, Castanon MJ, Wiche G: Plectin deficiency affects precursor formation and dynamics of vimentin networks. Exp Cell Res 2008;314:3570-3580.

229 Wiche G, Herrmann H, Leichtfried F, Pytela R: Plectin: a high-molecular-weight cytoskeletal polypeptide component that copurifies with intermediate filaments of the vimentin type. Cold Spring Harb Symp Quant Biol 1982;46:475-482.

230 Skalli O, Jones JC, Gagescu R, Goldman RD: IFAP 300 is common to desmosomes and hemidesmosomes and is a possible linker of intermediate filaments to these junctions. J Cell Biol 1994;125:159-170.

231 Kim H, Nakamura F, Lee W, Shifrin Y, Arora $\mathrm{P}, \mathrm{McCulloch} \mathrm{CA}$ : Filamin a is required for vimentin-mediated cell adhesion and spreading. Am J Physiol Cell Physiol 2010;298:C221-C236.

232 Song S, Hanson MJ, Liu BF, Chylack LT, Liang JJ: Protein-protein interactions between lens vimentin and alphab-crystallin using fret acceptor photobleaching. Mol Vis 2008; 14:1282-1287.

233 MacMillan-Crow LA, Lincoln TM: Highaffinity binding and localization of the cyclic GMP-dependent protein kinase with the intermediate filament protein vimentin. Biochemistry 1994;33:8035-8043.

234 Ciesielski-Treska J, Ulrich G, ChasserotGolaz S, Aunis D: Immunocytochemical localization of protein kinases Yes and Src in amoeboid microglia in culture: associa- tion of Yes kinase with vimentin intermediate filaments. Eur J Cell Biol 1995;68:369376.

235 Cary RB, Klymkowsky MW, Evans RM, Domingo A, Dent JA, Backhus LE: Vimentin's tail interacts with actin-containing structures in vivo. J Cell Sci 1994;107:16091622.

236 Gurland G, Gundersen GG: Stable, detyrosinated microtubules function to localize vimentin intermediate filaments in fibroblasts. J Cell Biol 1995;131:1275-1290.

237 Capetanaki Y, Smith S, Heath JP: Overexpression of the vimentin gene in transgenic mice inhibits normal lens cell differentiation. J Cell Biol 1989;109:1653-1664.

238 Kwak HI, Mendoza EA, Bayless KJ: ADAM17 co-purifies with TIMP-3 and modulates endothelial invasion responses in three-dimensional collagen matrices. Matrix Biol 2009;28:470-479.

239 Lee PF, Yeh AT, Bayless KJ: Nonlinear optical microscopy reveals invading endothelial cells anisotropically alter three-dimensional collagen matrices. Exp Cell Res 2009; 315:396-410.

240 Fisher KE, Sacharidou A, Stratman AN, Mayo AM, Fisher SB, Mahan RD, Davis MJ, Davis GE: MT1-MMP- and Cdc42-dependent signaling co-regulate cell invasion and tunnel formation in 3D collagen matrices. J Cell Sci 2009;122:4558-4569.

-241 Stratman AN, Saunders WB, Sacharidou A, Koh W, Fisher KE, Zawieja DC, Davis MJ, Davis GE: Endothelial cell lumen and vascular guidance tunnel formation requires MT1-MMP-dependent proteolysis in 3-dimensional collagen matrices. Blood 2009; 114:237-247.

242 Krishnan L, Hoying JB, Nguyen H, Song H, Weiss JA: Interaction of angiogenic microvessels with the extracellular matrix. Am J Physiol Heart Circ Physiol 2007; 293:H3650-H3658.

243 Contois L, Akalu A, Brooks PC: Integrins as 'Functional hubs' in the regulation of pathological angiogenesis. Semin Cancer Biol 2009; 19:318-328.

244 Akalu A, Cretu A, Brooks PC: Targeting integrins for the control of tumour angiogenesis. Expert Opin Investig Drugs 2005;14: 1475-1486.

245 Ghajar CM, Chen X, Harris JW, Suresh V, Hughes CC, Jeon NL, Putnam AJ, George SC: The effect of matrix density on the regulation of 3-D capillary morphogenesis. Biophys J 2008;94:1930-1941.

-246 Vernon RB, Sage EH: A novel, quantitative model for study of endothelial cell migration and sprout formation within threedimensional collagen matrices. Microvasc Res 1999;57:118-133.

247 Bayless KJ, Kwak HI, Su SC: Investigating endothelial invasion and sprouting behavior in three-dimensional collagen matrices. Nat Protoc 2009;4:1888-1898. 